\title{
Carbon Market Funding for the Development of Areas of Pastures: The Case of Small Farms in the State of Rio de Janeiro, Brazil
}

\author{
Fabiano Oliveira Chagas ${ }^{1}$, Osvaldo Luiz Gonçalves Quelhas ${ }^{1}$, Roberto Guimarães Pereira ${ }^{1} \&$ Valdir Lameira ${ }^{2}$ \\ ${ }^{1}$ Universidade Federal Fluminense, Rio de Janeiro, Brasil \\ ${ }^{2}$ University of Coimbra, Coimbra, Portugal \\ Correspondence: Fabiano Oliveira Chagas, Universidade Federal Fluminense, Rio de Janeiro, Brasil. Tel: \\ 98-935-574-6603. E-mail: fabiano.chagas@gmail.com
}

\author{
Received: April 12, 2013 Accepted: August 1, 2013 Online Published: November 22, 2013 \\ doi:10.5539/eer.v3n2p198 URL: http://dx.doi.org/10.5539/eer.v3n2p198
}

\begin{abstract}
This study aims to examine, within the Local Development, the reforestation with eucalyptus on land used for grazing. Uses the Market Certified Emission Reductions (CER) as a source for funding, through projects of Clean Development Mechanism (CDM). The study analyzes the cash flow of small-scale beef cattle operation and simulates the eucalyptus plantation on the farms. The area selected for this study covers the family-structured farms of small and medium extension on the beef cattle industry in north-central state of Rio de Janeiro, Brazil. The research method used was a literature review, application of the methodology recommended by the UN and cash flow analysis. Analysis of Net Present Value (NPV) considering the eucalyptus plantations for energy purposes, has brought positive values. The study confirms that the implementation of forestry along these models is itself a profitable activity. This study applied the methodology AR-AMS0001, recommended by the executive board of the United Nations on Climate Exchange.
\end{abstract}

Keywords: sustainable development, CDM for reforestation, engineering sustainability, local development

\section{Introduction}

The farms all over the state of Rio de Janeiro, whose source of income is agriculture and livestock, according to agricultural census of the Brazilian Institute of Geography and Statistics (CIDE, 2008) covers 1.6 million hectares. The cattle ranches basically depend on grazing and sugar cane, for the livestock maintenance and in some cases, a small farming focused not much more than subsistence. Many of these farms are maintained by families who hold possession of these areas because they are heirs of ancient estates, as presented in the study Nozoe (2006).

The work presented here aims to answer the following main question:

Is it financially and economically feasible to replace the beef cattle and milk production by small-scale eucalyptus plantations for siderurgical charcoal production and obtain financing through CDM forestry projects, after obtaining obtaining funding through forestry CDM projects?

The problem was investigated within the following economic and financial conditions observed in the Brazilian environment:

- Farmers who economically depends on the cattle on a small scale production have little chance to prosper economically;

- The charcoal supply for the steel industry does not fully address the necessary demand from steel producers, and the planned investments to increase forest for this purpose does not follow the same proportion of growth investments in steel production;

- The implementation of CDM forestry projects in Brazil for energy co-generation is a strategic alternative energy source to replace fossil fuels.

This paper aims to analyze the CDM implementation on forestry projects as a strategic alternative to the Local Development on underused areas focused so far only for grazing. 
Derive the following specific objectives:

- Run the economic and financial analysis of beef cattle and milk in the area where the research was performed;

- Studying the cash flow of a eucalyptus plantation in reforestation;

- Simulate an economic and financial planning to plant eucalyptus trees and cut trees on a 20 years plan to meet the siderurgical charcoal market demand.

The object of study are the farms of Rio de Janeiro's north-central area, which comprises Macae, Conceição de Macabu, Quissamã and Carapebus, family-owned small and medium extensions, between 25 and 60 hectares, and who use the cattle beef and milk as a source of income.

\section{Research Method}

We use a comparative study between the average income of livestock farms and the income from the quantification of Certified Emission Reduction (REC) from reforestation with eucalyptus sales to the charcoal market during 20 years.

The project CARBON FIX-TERRA BOA developed in Guararapes-Sao Paulo, Brazil, used this method in your project to calculate the reducing emissions of greenhouse gases through carbon sequestration by restoration of native forest. The area where the project was developed had been degraded due to its use as pasture area.

\section{Literature Review}

Green and Unruh (2010) in their study report that the implantation of CDM reforestation, such as the region studied here, generate positive impacts on local agriculture and increase income to the farmer, improving soil quality, increased capacity hydrographic investments in regional infrastructure, transfer of technology applied to agriculture, among others. However, the authors alert that there are potential risks of negative impacts that can limit the project implementation, such as the destruction of existing vegetation resources, increase threats of watter damage or even the decrease of watter availability.

The possible impacts caused on this type of implementation is not part of this document. On Brazil, by December 2010 only one forest carbon credits project won approval by the Authority designated as told by Puentes (2010). The project developed by Plantar S/A, entitled "Reforestation as Renewable Source of Wood Supply for Industrial Use in Brazil", aims to reduce GHG emissions in Brazilian metal industry and has an area of 11,700 hectares, located in the state of Minas Gerais, providing removal of 2.27 million tons of $\mathrm{CO}_{2}$ over a period of 30 years. Puentes (2010) continues, reporting that two other projects were under development in Brazil: the first is the AES Tiete to reforest areas for permanent preservation around the reservoirs of the Tietê River, an area of 8000 hectares can capture 2.7 million hectares of tonnes of $\mathrm{CO}_{2}$ in 30 years. The second is the Agroforestry Soroteca with 2319 hectares, removing 6.5 million tons of $\mathrm{CO}_{2}$ in 24 years.

Reforestation CDM projects worldwide are using the methodology AR-AMS0001 to support their estimates. Puentes (2010) cites in his dissertation projects in India, with reductions of 11.5 million tonnes of $\mathrm{CO}_{2}$ in Vietnam with reductions of 2.66 million tons of $\mathrm{CO}_{2}$, and in Bolivia, Paraguay and Uganda minors scales.

\subsection{Estimating Carbon Sequestration}

According to the Brazilian Agricultural Research Corporation-EMBRAPA (2002), it is known that the ability of fixation and carbon uptake by trees is directly dependent on the species, considering the growth rate, longevity, planted area, the climate and other variables.

The study conducted here does not consider the costs of hiring regulated firms to analyze the feasibility of implementing the CDM project, the implementation of the project itself, and also does not consider the costs of monitoring and audits to be conducted during the 21 years of project implementation.

According to the Brazilian Agricultural Research Corporation-EMBRAPA (2002), it is known that the ability of fixation and carbon uptake by trees is directly dependent on the species, considering the growth rate, longevity, planted area, the climate and other variables.

The study conducted here does not consider the costs of hiring regulated firms to analyze the feasibility of implementing the CDM project, the implementation of the project itself, and also does not consider the costs of monitoring and audits to be conducted during the 21 years of project implementation.

\subsubsection{Calculation Methodology Adopted}

In the proposed case study, the AR-AMS0001 methodology will be used, which becomes the "Methodology 
simplified baseline and monitoring of afforestation and reforestation small-scale project activities under the clean development mechanism implemented on grasslands". This methodology is approved by IPCC-NGGIP, as part of ONU, to evaluate the economic potential of the use of CDM projects as a source of funding.

The methodology presents a series of equations for calculation, divided into two sections: the first is the baseline calculation and the second section is reserved for the monitoring processes.

The methodology provides equations to calculate:

- Carbon stock baseline;

- The above ground biomass estimates;

- Underground biomass estimates;

- Carbon stock below ground estimates;

- Baseline removal of Greenhouse gases within the project area;

- Calculation of identified leakage;

\section{- RCE.}

At the Monitoring section, there are equations to perform the following calculations:

- Carbon stocks of above-ground biomass;

- Carbon stocks in below-ground biomass;

- Measuring leakages;

- Net GHG removal calculation;

- Monitoring frequency.

\subsection{Financial Analysis and Projections}

To perform a detailed analysis of the feasibility of a project some mathematical equations were used-financial, where part of a baseline and projections based on statistical simulations.

In these sections it applies methods of mathematical and financial for the following scenarios:

- Small-scale farms;

- Wood market for charcoal from eucalyptus reforestation covering 11/12 of the pasture area;

- Implementation of CDM project to carbon credits market in the reforested area.

\section{Data Collection and Analysis, and Proposed Use of Carbon Credit Market or Local Development} Growth

\subsection{Estimate of Economic and Financial Beef Cattle and Milk in the Region}

Schier (2005), on his research, uses the principles of full absorption costing, which seeks to allocate the entire cost of producing the products.

The method described by Schier (2005) to calculate the full absorption costing considers the following variables:

- Expenses related to production (fixed and variable), which are treated as "sales cost";

- Net sales less cost of goods sold, resulting in gross profit for the period;

- Gross profit less the expenses of the period resulting in profit before applying taxes and social contribution on net income;

- When the production period is not totally sold, products in stock so go to the next period.

In this study, the following assumptions were made for the parameterization of the calculations for the determination of the cost:

- For the milk market, the entire production is purchased by the dairy cooperatives in the city;

- Regarding to beef cattle market, when a farmer has availability to sell, there are never problems in abattoirs and / or butchers cities in buying the squad;

- To consider these two items, the research will not be considered the remaining stock or it was not sold in the period, the milk is harvested or weight of cattle for slaughter;

- Since the raw material is nothing else than the amount of productive livestock that the farmer has, and knowing 
that we are dealing with two distinct markets with the same ingredient (beef and milk), the cost of raw materials will result from the amount of productive animals and their depreciation;

- As characteristic of the region, because the flock feed predominantly on pasture, the cost of feeding livestock are derisory;

- The reproduction takes place by natural procedures, excluding the need to carry out artificial insemination. Therefore, there is no cost involved with insemination.

\subsubsection{Accounting and Financial Analysis of Beef Cattle and Milk}

For this study, the sample was taken for a property in the county of Macabuzinho in the city of Conceição de Macabu which has 72.5 hectares. Of these, 3 hectares for planting sugarcane, 1 hectare to the farmhouse and barn and all the rest, 67.5 acres for grazing. The property has 139 head of cattle crossbred with 98 matrices, 1 and 40 breeding males for fattening and subsequent sale for slaughter. This is scenario of livestock for the dairy industry used in this research.

\subsubsection{Roster Maintenance}

Using the method of calculating the cost of milk production Segala and Silva (2007), we have in Table 1 the distribution of cows for a period of 4 months.

Table 1. Distribution of the squad for a period of four months

\begin{tabular}{lcccc}
\hline Number of cows selected for reproduction & nov/09 & Dec/09 & jan/10 & Feb/10 \\
\hline In lactation & 61 & 58 & 58 & 62 \\
Dry & 18 & 19 & 20 & 19 \\
Heifers and heifer calves & 19 & 21 & 19 & 18 \\
I cannot find precise English equivalent & 98 & 98 & 97 & 99 \\
\hline
\end{tabular}

The squad has an average of 59 cows with this characteristic and applied to the purchase price of the matrices is $\$ 2,000.00$ already in milk production. Table 2 shows the monthly depreciation based on the presented data.

Table 2. Depreciation of matrices for the milk production

\begin{tabular}{cccccc}
\hline Matrizes & $\begin{array}{c}\text { Valor de } \\
\text { compra }\end{array}$ & Valor total & $\begin{array}{c}\text { Depreciaçã } \\
\text { o por ano }\end{array}$ & $\begin{array}{c}\% \\
\text { depreciação } \\
\text { por mês }\end{array}$ & $\begin{array}{c}\text { Valor depreciado } \\
\text { por mês }\end{array}$ \\
\hline $\begin{array}{c}59 \text { in the production } \\
\text { phase - Nov-09 }\end{array}$ & 2000 & $\mathrm{R} \$ 122.000,00$ & $10 \%$ & $0,83 \%$ & $\mathrm{R} \$ 1.012,60$ \\
$\begin{array}{c}58 \text { in the production } \\
\text { phase - Dec-09 }\end{array}$ & 2000 & $\mathrm{R} \$ 116.000,00$ & $10 \%$ & $0,83 \%$ & $\mathrm{R} \$ 962,80$ \\
$\begin{array}{c}58 \text { in the production } \\
\text { phase - Jan-10 }\end{array}$ & 2000 & $\mathrm{R} \$ 116.000,00$ & $10 \%$ & $0,83 \%$ & $\mathrm{R} \$ 962,80$ \\
62 in the production \\
phase - Feb-10
\end{tabular}

Source: Research data.

About the energy costs were considered using a water pump used to clean and supply water tank, the equipment that keeps the refrigerated tank, forage harvester, tractor, milking equipment of the cane shredder (forage). At the time of getting vaccinated animals, buying up a lot for all the flock, and the cutting of milk plus a margin of $10 \%$, so there is not a control vaccination per individual. On the farm, working directly with cattle in milk production the owner and one employee.

Table 3 shows the relationship of equipment and machinery used directly or indirectly for the milk production. Similarly the research used by Segala and Silva (2007), data were parameterized to contemplate the reality of the 
farm, and therefore the region.

Table 3. Monthly Depreciation of equipment

\begin{tabular}{lcccccc}
\hline \multicolumn{1}{c}{ Item } & $\begin{array}{c}\text { Purchase } \\
\text { amount }\end{array}$ & $\begin{array}{c}\text { Purchase } \\
\text { year }\end{array}$ & $\begin{array}{c}\text { Annual } \\
\text { depreciation }\end{array}$ & $\begin{array}{c}\text { Percentage } \\
\text { of use }\end{array}$ & $\begin{array}{c}\text { Percentage of } \\
\text { use in other } \\
\text { activities }\end{array}$ & $\begin{array}{c}\text { Monthly } \\
\text { depreciation } \\
\text { amount }\end{array}$ \\
\hline Forage & $\mathrm{R} \$ 9.700,00$ & 2001 & $14,28 \%$ & $100 \%$ & $0 \%$ & $\mathrm{R} \$ 115,43$ \\
Milking & $\mathrm{R} \$ 30.000,00$ & 2004 & $10,00 \%$ & $100 \%$ & $0 \%$ & $\mathrm{R} \$ 250,00$ \\
Cooler & $\mathrm{R} \$ 28.000,00$ & 2005 & $6,67 \%$ & $100 \%$ & $0 \%$ & $\mathrm{R} \$ 155,63$ \\
Mowing & $\mathrm{R} \$ 2.800,00$ & 2003 & $10,00 \%$ & $50 \%$ & $50 \%$ & $\mathrm{R} \$ 23,33$ \\
Feed truck & $\mathrm{R} \$ 30.000,00$ & 2002 & $10,00 \%$ & $20 \%$ & $80 \%$ & $\mathrm{R} \$ 250,00$ \\
Water pump & $\mathrm{R} \$ 380,00$ & 2000 & $5,00 \%$ & $60 \%$ & $40 \%$ & $\mathrm{R} \$ 1,58$ \\
Equipment's monthly depreciation & & & & & $\mathrm{R} \$ 795,98$ \\
\hline
\end{tabular}

Source: Research data, adapted to Segala and Silva (2007).

Table 4 below, is presented the calculation of depreciation of buildings and facilities that are designed to produce milk.

Table 4. Estimated monthly depreciation for facilities

\begin{tabular}{|c|c|c|c|c|c|c|}
\hline Item & $\begin{array}{l}\text { Investment } \\
\text { value }\end{array}$ & $\begin{array}{c}\text { Purchase } \\
\text { year }\end{array}$ & $\begin{array}{c}\text { Annual } \\
\text { depreciation }\end{array}$ & $\begin{array}{l}\text { Utilization } \\
\text { percentage }\end{array}$ & $\begin{array}{c}\text { Utilization } \\
\text { percentage in } \\
\text { other activities }\end{array}$ & $\begin{array}{c}\text { Monthly } \\
\text { depreciation }\end{array}$ \\
\hline Covered corral & $\begin{array}{c}\mathrm{R} \$ 70.000,0 \\
0\end{array}$ & 2001 & $4 \%$ & $100 \%$ & $0 \%$ & $\mathrm{R} \$ 233,33$ \\
\hline Machinery shed & $\begin{array}{c}\mathrm{R} \$ 25.000,0 \\
0\end{array}$ & 2001 & $4 \%$ & $33 \%$ & $67 \%$ & $\mathrm{R} \$ 83,33$ \\
\hline Employee housing & $\begin{array}{c}\mathrm{R} \$ 20.000,0 \\
0\end{array}$ & 2001 & $4 \%$ & $100 \%$ & $0 \%$ & $\mathrm{R} \$ 66,67$ \\
\hline Fences & $\begin{array}{c}\mathrm{R} \$ 10.000,0 \\
0\end{array}$ & 2000 & $10 \%$ & $100 \%$ & $0 \%$ & $\mathrm{R} \$ 83,33$ \\
\hline Power grid & $\begin{array}{c}\mathrm{R} \$ 10.000,0 \\
0\end{array}$ & 1999 & $10 \%$ & $100 \%$ & $0 \%$ & $\mathrm{R} \$ 83,33$ \\
\hline $\begin{array}{l}\text { Water/plumbing } \\
\text { network }\end{array}$ & $\begin{array}{c}\mathrm{R} \$ 10.000,0 \\
0\end{array}$ & 1999 & $10 \%$ & $20 \%$ & $80 \%$ & $\mathrm{R} \$ 83,33$ \\
\hline Breeding bull & $\mathrm{R} \$ 5.000,00$ & 1999 & $10 \%$ & $100 \%$ & $0 \%$ & $\mathrm{R} \$ 41,67$ \\
\hline \multicolumn{6}{|c|}{ Monthly depreciation of facilities } & $\mathrm{R} \$ 675,00$ \\
\hline
\end{tabular}

Source: Research data, adapted to Segala and Silva (2007).

\subsubsection{Overall Production Costs}

From these surveys covering up the front approaches and adaptations to research Segala and Silva (2007), Table 5 , below was generated, and presents a summary of the realized values, containing the calculation of the monthly average cost of milk production. On not considering the depreciation, the value of production would decrease a lot, and it is shown in Table 6 below. 
Table 5. Overall cost production

\begin{tabular}{|c|c|c|c|c|c|c|c|c|}
\hline $\begin{array}{l}\text { Cost of Milk } \\
\text { Production }\end{array}$ & $\begin{array}{c}\text { November } \\
2010\end{array}$ & $\begin{array}{c}\text { Vertica } \\
1 \\
\text { analysi } \\
\text { s }\end{array}$ & $\begin{array}{l}\text { December } \\
2010\end{array}$ & $\begin{array}{c}\text { Vertica } \\
1 \\
\text { analysi } \\
\text { s }\end{array}$ & $\begin{array}{c}\text { January } \\
2010\end{array}$ & $\begin{array}{c}\text { Vertica } \\
1 \\
\text { analysi } \\
\text { s }\end{array}$ & $\begin{array}{c}\text { February } \\
2010\end{array}$ & $\begin{array}{c}\text { Vertical } \\
\text { analysi } \\
\text { s }\end{array}$ \\
\hline Fuel & $\mathrm{R} \$ 400,00$ & $5,72 \%$ & $\mathrm{R} \$ 400,00$ & $5,73 \%$ & $\mathrm{R} \$ 400,00$ & $5,76 \%$ & $\mathrm{R} \$ 400,00$ & $5,70 \%$ \\
\hline $\begin{array}{c}\text { Light } \\
\text { consumption }\end{array}$ & $\mathrm{R} \$ 800,00$ & $11,43 \%$ & $\mathrm{R} \$ 800,00$ & $11,46 \%$ & $\mathrm{R} \$ 800,00$ & $11,52 \%$ & $\mathrm{R} \$ 800,00$ & $11,41 \%$ \\
\hline $\begin{array}{c}\text { Facility } \\
\text { depreciation }\end{array}$ & $\mathrm{R} \$ 675,00$ & $9,65 \%$ & $\mathrm{R} \$ 675,00$ & $9,67 \%$ & $\mathrm{R} \$ 675,00$ & $9,72 \%$ & $\mathrm{R} \$ 675,00$ & $9,63 \%$ \\
\hline $\begin{array}{l}\text { Depreciation } \\
\text { of matrices }\end{array}$ & $\mathrm{R} \$ 1.012,60$ & $14,47 \%$ & $\mathrm{R} \$ 962,80$ & $13,79 \%$ & $\mathrm{R} \$ 962,80$ & $13,86 \%$ & $\mathrm{R} \$ 1.029,20$ & $14,68 \%$ \\
\hline $\begin{array}{l}\text { Depreciation } \\
\text { of machinery } \\
\text { and equipment }\end{array}$ & $\mathrm{R} \$ 795,98$ & $11,37 \%$ & $\mathrm{R} \$ 795,98$ & $11,40 \%$ & $\mathrm{R} \$ 795,98$ & $11,46 \%$ & $\mathrm{R} \$ 795,98$ & $11,35 \%$ \\
\hline $\begin{array}{c}\text { Service, } \\
\text { maintenance } \\
\text { and cleaning }\end{array}$ & $\mathrm{R} \$ 45,00$ & $0,64 \%$ & $\mathrm{R} \$ 45,00$ & $0,64 \%$ & $\mathrm{R} \$ 45,00$ & $0,65 \%$ & $\mathrm{R} \$ 45,00$ & $0,64 \%$ \\
\hline $\begin{array}{l}\text { Medicine, } \\
\text { vaccines, and } \\
\text { veterinary }\end{array}$ & $\mathrm{R} \$ 114,50$ & $1,64 \%$ & $\mathrm{R} \$ 148,00$ & $2,12 \%$ & $\mathrm{R} \$ 112,00$ & $1,61 \%$ & $\mathrm{R} \$ 112,00$ & $1,60 \%$ \\
\hline $\begin{array}{l}\text { Salaries } \\
\text { (including } \\
\text { charges) }\end{array}$ & $\mathrm{R} \$ 3.154,60$ & $45,08 \%$ & $\mathrm{R} \$ 3.154,60$ & $45,19 \%$ & $\mathrm{R} \$ 3.154,60$ & $45,42 \%$ & $\mathrm{R} \$ 3.154,60$ & $44,99 \%$ \\
\hline Total costs & $\mathrm{R} \$ 6.997,68$ & $100 \%$ & $\mathrm{R} \$ 6.981,38$ & $100 \%$ & $\mathrm{R} \$ 6.945,38$ & $100 \%$ & $\mathrm{R} \$ 7.011,78$ & $100 \%$ \\
\hline $\begin{array}{l}\text { Monthly milk } \\
\text { production }\end{array}$ & 21960 & litros & 20880 & litros & 20880 & litros & 22320 & litros \\
\hline $\begin{array}{l}\text { Cost per liter } \\
\text { of milk }\end{array}$ & $\mathrm{R} \$ 0,32$ & & $\mathrm{R} \$ 0,33$ & & $\mathrm{R} \$ 0,33$ & & $\mathrm{R} \$ 0,31$ & \\
\hline $\begin{array}{c}\text { Selling price } \\
\text { per liter }\end{array}$ & $\mathrm{R} \$ 0,65$ & & $\mathrm{R} \$ 0,65$ & & $\mathrm{R} \$ 0,65$ & & $\mathrm{R} \$ 0,65$ & \\
\hline $\begin{array}{l}\text { Profit or loss } \\
\text { per liter of } \\
\text { milk produced }\end{array}$ & $\mathrm{R} \$ 0,33$ & & $\mathrm{R} \$ 0,32$ & & $\mathrm{R} \$ 0,32$ & & $\mathrm{R} \$ 0,34$ & \\
\hline $\begin{array}{l}\text { Monthly } \\
\text { revenue }\end{array}$ & $\mathrm{R} \$ 7.276,32$ & & $\mathrm{R} \$ 6.590,62$ & & $\mathrm{R} \$ 6.626,62$ & & $\mathrm{R} \$ 7.496,22$ & \\
\hline
\end{tabular}

Source: Research data, adapted to Segala and Silva (2007). 
Table 6. Overall cost production excluding depreciation

\begin{tabular}{|c|c|c|c|c|c|c|c|c|}
\hline $\begin{array}{l}\text { Cost of Milk } \\
\text { Production }\end{array}$ & $\begin{array}{c}\text { November } \\
2010\end{array}$ & $\begin{array}{l}\text { Vertical } \\
\text { analysis }\end{array}$ & $\begin{array}{c}\text { December } \\
2010\end{array}$ & $\begin{array}{l}\text { Vertical } \\
\text { analysis }\end{array}$ & January 2010 & $\begin{array}{l}\text { Vertical } \\
\text { analysis }\end{array}$ & $\begin{array}{c}\text { February } \\
2010\end{array}$ & $\begin{array}{l}\text { Vertical } \\
\text { analysis }\end{array}$ \\
\hline Fuel & $\mathrm{R} \$ 400,00$ & $8,86 \%$ & $\mathrm{R} \$ 400,00$ & $8,80 \%$ & $\mathrm{R} \$ 400,00$ & $8,87 \%$ & $\mathrm{R} \$ 400,00$ & $8,87 \%$ \\
\hline $\begin{array}{c}\text { Light } \\
\text { consumption }\end{array}$ & $\mathrm{R} \$ 800,00$ & $17,72 \%$ & $\mathrm{R} \$ 800,00$ & $17,59 \%$ & $\mathrm{R} \$ 800,00$ & $17,73 \%$ & $\mathrm{R} \$ 800,00$ & $17,73 \%$ \\
\hline $\begin{array}{c}\text { Service, } \\
\text { maintenance, } \\
\text { and cleaning }\end{array}$ & $\mathrm{R} \$ 45,00$ & $1,00 \%$ & $\mathrm{R} \$ 45,00$ & $0,99 \%$ & $\mathrm{R} \$ 45,00$ & $1,00 \%$ & $\mathrm{R} \$ 45,00$ & $1,00 \%$ \\
\hline $\begin{array}{l}\text { Medicine, } \\
\text { vaccines, and } \\
\text { veterinary }\end{array}$ & $\mathrm{R} \$ 114,50$ & $2,54 \%$ & $\mathrm{R} \$ 148,00$ & $3,25 \%$ & $\mathrm{R} \$ 112,00$ & $2,48 \%$ & $\mathrm{R} \$ 112,00$ & $2,48 \%$ \\
\hline $\begin{array}{l}\text { Salaries } \\
\text { (including } \\
\text { charges) }\end{array}$ & $\mathrm{R} \$ 3.154,60$ & $69,88 \%$ & $\mathrm{R} \$ 3.154,60$ & $69,37 \%$ & $\mathrm{R} \$ 3.154,60$ & $69,92 \%$ & $\mathrm{R} \$ 3.154,60$ & $69,92 \%$ \\
\hline Total costs & $\mathrm{R} \$ 4.514,10$ & $100 \%$ & $\mathrm{R} \$ 4.547,60$ & $100 \%$ & $\mathrm{R} \$ 4.511,60$ & $100 \%$ & $\mathrm{R} \$ 4.511,60$ & $100 \%$ \\
\hline $\begin{array}{l}\text { Monthly Milk } \\
\text { Production }\end{array}$ & 21960 & litros & 20880 & litros & 20880 & litros & 22320 & litros \\
\hline $\begin{array}{l}\text { Cost per liter of } \\
\text { milk }\end{array}$ & $\mathrm{R} \$ 0,21$ & & $\mathrm{R} \$ 0,22$ & & $\mathrm{R} \$ 0,22$ & & $\mathrm{R} \$ 0,20$ & \\
\hline $\begin{array}{l}\text { Selling price per } \\
\text { liter }\end{array}$ & $\mathrm{R} \$ 0,65$ & & $\mathrm{R} \$ 0,65$ & & $\mathrm{R} \$ 0,65$ & & $\mathrm{R} \$ 0,65$ & \\
\hline $\begin{array}{c}\text { Profit or loss per } \\
\text { liter of milk } \\
\text { produced }\end{array}$ & $\mathrm{R} \$ 0,44$ & & $\mathrm{R} \$ 0,43$ & & $\mathrm{R} \$ 0,43$ & & $\mathrm{R} \$ 0,45$ & \\
\hline $\begin{array}{l}\text { Monthly } \\
\text { revenue }\end{array}$ & $\mathrm{R} \$ 9.759,90$ & & $\mathrm{R} \$ 9.024,40$ & & $\mathrm{R} \$ 9.060,40$ & & $\mathrm{R} \$ 9.996,40$ & \\
\hline
\end{tabular}

Source: Data from the survey, adapted the Segala and Silva (2007).

\subsubsection{Values from the Slaughter Sales Operation}

On the farm taken per sample, born approximately 45 males and 45 females annually, which represents 6-7 animals per month. Females are focused exclusively milk production and thus replacing the animals leaving the productive period and headed to slaughter. Table 7 shows the estimated annual births in the farm and the amount of animals that are fattening and subsequent slaughter. Table 8 shows the projected monthly revenue considering the income with cattle for slaughter. The price for the animal is published on an electronic online service market for cattle in Brazil (PECUARIA, 2012).It was taken the value of cattle for slaughter by $\mathrm{R} \$ 1,170.00$ and $\mathrm{R}$ $\$ 880.00$ for the female.

Table 7. Estimated monthly revenue with cattle

\begin{tabular}{ccccccc}
\hline $\begin{array}{c}\text { Number of } \\
\text { animals born }\end{array}$ & Per year & $\begin{array}{c}\text { Females To } \\
\text { Reset Milk } \\
\text { Production }\end{array}$ & $\begin{array}{c}\text { Annual } \\
\text { surplus }\end{array}$ & $\begin{array}{c}\text { Monthly } \\
\text { for } \\
\text { slaughter }\end{array}$ & $\begin{array}{c}\text { Price of the } \\
\text { animal for } \\
\text { slaughter }\end{array}$ & $\begin{array}{c}\text { Value } \\
\text { calculated on } \\
\text { sale }\end{array}$ \\
\hline Males & 42 & 0 & 42 & 3 & $\mathrm{R} \$ 1.170,00$ & $\mathrm{R} \$ 3.510,00$ \\
Females & 42 & 8 & 34 & 2 & $\mathrm{R} \$ 880,00$ & $\mathrm{R} \$ 1.760,00$ \\
Total & & & & & & $\mathrm{R} \$ 5.270,00$ \\
\hline
\end{tabular}


Table 8 . Forecast monthly and annual revenue of ranching family

\begin{tabular}{|c|c|c|c|c|c|c|}
\hline $\begin{array}{c}\text { Without } \\
\text { Depreciation }\end{array}$ & Month 1 & Month 2 & Month 3 & Month 4 & $\begin{array}{c}\text { Average } \\
\text { monthly value }\end{array}$ & $\begin{array}{c}\text { Average annual } \\
\text { value }\end{array}$ \\
\hline Milk Revenue & $\mathrm{R} \$ 9.759,90$ & $\mathrm{R} \$ 9.024,40$ & $\mathrm{R} \$ 9.060,40$ & $\mathrm{R} \$ 9.996,40$ & $\mathrm{R} \$ 9.460,28$ & $\mathrm{R} \$ 113.523,30$ \\
\hline Revenue Cut & $\mathrm{R} \$ 5.270,00$ & $\mathrm{R} \$ 5.270,00$ & $\mathrm{R} \$ 5.270,00$ & $\mathrm{R} \$ 5.270,00$ & $\mathrm{R} \$ 5.270,00$ & $\mathrm{R} \$ 63.240,00$ \\
\hline Balance & $R \$ 15.029,90$ & $R \$ 14.294,40$ & $R \$ 14.330,40$ & $R \$ 15.266,40$ & $R \$ 14.730,28$ & $R \$ 176.763,30$ \\
\hline $\begin{array}{c}\text { With } \\
\text { depreciation }\end{array}$ & Month 1 & Month 2 & Month 3 & Month 4 & $\begin{array}{c}\text { Average } \\
\text { monthly value }\end{array}$ & $\begin{array}{c}\text { Average annual } \\
\text { value }\end{array}$ \\
\hline Milk Revenue & $\mathrm{R} \$ 7.276,32$ & $\mathrm{R} \$ 6.590,62$ & $\mathrm{R} \$ 6.626,62$ & $\mathrm{R} \$ 7.496,22$ & $\mathrm{R} \$ 6.997,45$ & $\mathrm{R} \$ 83.969,34$ \\
\hline Revenue Cut & $\mathrm{R} \$ 5.270,00$ & $\mathrm{R} \$ 5.270,00$ & $\mathrm{R} \$ 5.270,00$ & $\mathrm{R} \$ 5.270,00$ & $\mathrm{R} \$ 5.270,00$ & $\mathrm{R} \$ 63.240,00$ \\
\hline Balance & $R \$ 12.546,32$ & $R \$ 11.860,62$ & $R \$ 11.896,62$ & $R \$ 12.766,22$ & $R \$ 12.267,45$ & $R \$ 147.209,34$ \\
\hline
\end{tabular}

\subsection{Simulation of Eucalyptus Plantation}

The survey includes soil preparation, planting and harvesting in two scenarios: with 67.5 ranch. Based on the forecast growth generated by SisEucalipto, Table 9 shows the growth trend as volume and curves Current Annual Increment (ICA) and Mean Annual Increment (MAI).By ICA has growth volume occurred within one year, and IMA to the result of dividing the volume by the age of the forest. Note that the curve ICA reaches a maximum value before the curve IMA, the 8th year of planting, and that the two curves intersect at the point of maximum IMA.

Table 9. Prognosis of forest yield per hectare planted eucalyptus

\begin{tabular}{ccccccccc}
\hline Age & $\begin{array}{c}\text { Dominant } \\
\text { height }(\mathrm{m})\end{array}$ & trees/ Ha & $\begin{array}{c}\text { Average } \\
\text { diameter }(\mathrm{cm})\end{array}$ & $\begin{array}{c}\text { Average } \\
\text { height }(\mathrm{m})\end{array}$ & $\begin{array}{c}\text { Basal } \\
\text { Area }\left(\mathrm{cm}^{2}\right)\end{array}$ & $\begin{array}{c}\text { Total Volume } \\
\left(\mathrm{m}^{3}\right)\end{array}$ & I.M.A. & I.C.A. \\
\hline 1 & 4,3 & 1650 & 4 & 3,6 & 2 & 3 & 3 & 3 \\
2 & 9,7 & 1650 & 10,3 & 8,1 & 13,7 & 45,9 & 22,9 & 42,9 \\
3 & 13,8 & 1650 & 14 & 11,6 & 25,4 & 122 & 40,7 & 76,1 \\
4 & 17,1 & 1648 & 16,4 & 14,4 & 34,7 & 206,1 & 51,5 & 84,1 \\
5 & 19,7 & 1646 & 18 & 16,6 & 42 & 288 & 57,6 & 81,9 \\
6 & 22 & 1642 & 19,2 & 18,4 & 47,8 & 364,3 & 60,7 & 76,3 \\
7 & 23,9 & 1638 & 20,2 & 20 & 52,4 & 434,2 & 62 & 69,9 \\
8 & 25,5 & 1633 & 20,9 & 21,4 & 56,3 & 497,6 & 62,2 & 63,4 \\
9 & 26,9 & 1628 & 21,6 & 22,6 & 59,4 & 555,1 & 61,7 & 57,5 \\
\hline
\end{tabular}

Source: Research data generated by SisEucalipto.

Forest cycle is driving the growth of the buds of trees newly planted or freshly cut. To consider the horizon of 21 years and cuts every 7 years, the analysis is based on three cycles forest.

The information presented by the work of EMBRAPA are based on surveys conducted with farmers where its properties include planting pine and eucalyptus as a production system.

For operations of planting and cultivation of eucalyptus should be considered:

- Preparation area;

- Planting;

- Weed control;

- Age cut-off;

- Costs;

- Productivity; 
In the simulation hypothesis of this project was performed to analyze the planting of Eucalyptus urograndis in Conceição de Macabu property that was taken per sample, 67.5.Estimates were calculated from the values suggested in the EMBRAPA research (2005) and CEPEA-Center for Advanced Studies in Applied Economics from USP.

It has a stereo equivalent to $1 \mathrm{~m}^{3}$ of wood, commonly used measurement unit in the market forester. The CEPEA published in his newsletter in the month of Forestry September/2012 that the average value of the stereo stand for the energy market is priced at $\$ 50,00$.However, in considering whether a more conservative estimate, taking as reference values proposed by the Forestry Program of Arcelor Mittal (2008), the value of the stereo is $\$ 20.00$. These values composes Table 10 .

Table 10. Forecast of revenue cycle for forest planting in 65 hectares

\begin{tabular}{|c|c|c|c|c|}
\hline Production and income & $\begin{array}{c}\text { Volume } \\
\text { produced } \\
\text { by } 7 \text {-year } \\
\text { forest } \\
\text { cycle } \\
\left(\mathrm{m}^{3} / \mathrm{ha}\right)\end{array}$ & $\begin{array}{c}\text { Stere } \\
\text { Value } \\
\text { (Value } \\
\text { provided } \\
\text { by } \\
\text { CEPEA) }\end{array}$ & $\begin{array}{l}\text { Estimated } \\
\text { revenue } \\
\text { per hectare }\end{array}$ & $\begin{array}{l}\text { Revenue generated } \\
\text { by } \\
\text { forest cycle ( } 65 \text { ha } \\
\text { of forest) }\end{array}$ \\
\hline Stere Value (supplied by CEPEA) & 434,2 & $\mathrm{R} \$ 50,00$ & $\mathrm{R} \$ 21.710,00$ & $\mathrm{R} \$ 1.411 .150,00$ \\
\hline Stere Value (suggested by ArcelorMittal) & 434,2 & $\mathrm{R} \$ 20,00$ & $\mathrm{R} \$ 8.684,00$ & $\mathrm{R} \$ 564.460,00$ \\
\hline
\end{tabular}

\subsection{Execution of the Calculations According to the Methodology AR-AMS0001}

With respect to this research project, the selected methodology is the AR-AMS0001, "Exhibit A", which is to be applied in reforestation projects carried out in the pastures.

\subsubsection{Baseline GHG Removal at the Sinkhole}

The calculation methodology provides equations to calculate:

- The above ground biomass estimates;

- Underground biomass estimates;

- Baseline the baseline removal of Greenhouse gases (GHG) in the vicinity of the project;

- Estimated leakage calculation;

- RCE.

Some of the equations are presented in this summary. The equation 3.1 brings as a result the stock of carbon in living biomass in the project region.

$$
B(t)=\sum_{i=1}^{I}\left(B(t)+B_{i B(t) i}\right) * A_{i}
$$

Where:

$B_{(t)}=$ the carbon stock in living biomass in the project region at time $(\mathrm{t})$ the absence of project activity expressed in $\mathrm{tC}$ (tonne of carbon);

${ }_{B(t)}={ }_{i}$ is the biomass carbon stock above ground so in time $(t)$ of the stratum $(i)$ in the absence of the project activity expressed in $\mathrm{t} \mathrm{C} / \mathrm{ha}$ (tons of carbon per hectare);

$B_{B(t)}={ }_{i}$ is the carbon stock in below-ground biomass at time $(\mathrm{t})$ of the stratum

(I) in the absence of the project activity expressed in $\mathrm{t} \mathrm{C} / \mathrm{ha}$ (tons of carbon per hectare);

$A_{(i)}=$ Area of stratum design expressed in ha (hectares);

$i=$ stratum $\mathrm{i}(\mathrm{i}=$ total number of strata). 


\subsubsection{Calculation of Above Ground Biomass}

To calculate the above-ground biomass, uses the following equation:

$$
B_{a(t)}=M_{(t)} * 0.5
$$

Where:

$B(t)=$ carbon stock in aboveground biomass in the year (time) $t$ when the lack of implementation of the project, expressed in $\mathrm{t} \mathrm{C} / \mathrm{ha}$ (tons of carbon per hectare);

$M_{(t)}=$ above-ground biomass in the year (time) $t$ when the lack of implementation of the project, expressed in $\mathrm{t}$ $\mathrm{dm} / \mathrm{ha}$ (tons of dry matter per hectare);

$0.5=$ carbon fraction of dry matter expressed in $\mathrm{t} \mathrm{C} / \mathrm{t} \mathrm{dm}$ (tonne of carbon per tonne of dry matter).

Table 11 is the simulation of the carbon stock of above-ground biomass, year-on-year.

Table 11. Biomass carbon stocks above ground every year

\begin{tabular}{cccccc}
\hline$M$ & $M_{\text {woody }}$ & $\begin{array}{c}M_{\text {woody }(t=n-1)}+g * D t \\
+g *\end{array}$ & $\begin{array}{c}M \\
\text { woody_max }\end{array}$ & $M_{(t=n)}$ & $\begin{array}{c}B_{a(t)}=M_{(t)} \\
* 0.5\end{array}$ \\
\hline $\begin{array}{c}\{0\} 6.2\{/ 0\}\{1\} \\
\{/ 1\}\end{array}$ & 0 & 0 & 0 & $\begin{array}{c}\{0\} 6.2\{/ 0\}\{1\} \\
\{/ 1\}\end{array}$ & 3.1 \\
\hline
\end{tabular}

\subsubsection{Calculation of Biomass Below Ground}

The methodology guides to be performed to calculate the below-ground biomass, as it also does capture carbon from the atmosphere by being an organism alive. This calculation considers the roots of grass and evergreen trees.

Table 12 is the simulation of the carbon stock in below-ground biomass, year-on-year.

Table 12. Biomass carbon stocks below the ground each year

\begin{tabular}{|c|c|c|c|c|c|c|}
\hline Mgrass & Rgrass & Mwoody & Rwoody & $\begin{array}{c}\text { Mwoody }(t=n-1)+ \\
g * \Delta t) * R \text { woody }\end{array}$ & Mwoody_max & $\begin{array}{c}B_{B(t=n)}=0,5 * \\
{\left[M_{\text {grass }} * R_{\text {grass }}+\left(M_{\text {woody }(t=n-l)}+g\right.\right.} \\
\left.* \Delta t) * R_{\text {woody }}\right]\end{array}$ \\
\hline 6,2 & 1,58 & 0 & 1 & 0 & 0 & 4,898 \\
\hline
\end{tabular}

4.3.4 Calculation of Baseline Actual Removal of Greenhouse Gases

To then determine the baseline actual removal of greenhouse gases in the analyzed region follows the equation:

$$
\Delta_{B S L C, t}=\left({ }_{(B(t)}-B_{(t-1)}\right) *\left(_{(44 / 12)}\right)
$$

Hence:

$\triangle C B S L, t=$ Baseline actual removal of greenhouse gases by sinks

$B_{(t)}=$ carbon stock in living biomass in the year (time) $t$ would exist when the lack of implementation of the project, expressed as $\mathrm{C} t$ (tonne of carbon);

To be considered for Tables 12 and 13, which inform the biomass carbon in the study area, the change from baseline removal Greenhouse Gases is zero throughout the project:

$$
\begin{gathered}
B_{(t)}=B_{(t-1)}=> \\
\Delta_{B S L C, t}=\left(B(t)-B_{(t))}\right) *((44 / 12)) \\
\Delta C_{B S L, t}=0 *(44 / 12) \\
\Delta C_{B S L, t}=0
\end{gathered}
$$

Thus, the resulting equation for calculating the baseline carbon stock in the absence of the project activity during the period of the hypothesis: 


$$
B(t)=\sum_{i=1}^{I}\left(B(t)+B_{i B(t) i}\right) * A_{i}
$$

Adding Tables 11 and 12 then have the result in Table 13, with the baseline of the reference scenario.

Table 13. Baseline carbon stock of the reference scenario every year

\begin{tabular}{cccc}
\hline$B_{a(t) I}$ & ${ }_{B} B_{(t) i}$ & $A$ & $B_{(t)}$ \\
\hline 3.1 & 4898 & 1,000 & 7998 \\
\hline
\end{tabular}

To consider that the methodology is only biomass above and below ground, not treating emissions from food, in the case of this research project, cattle, this issue was not considered in the calculations.

\subsubsection{Designed Calculation Baseline in Project Implementation (ex ante)}

According to the methodology, the carbon stock in the scenario that will occur in the project implementation start date of activity $(t=0)$ must be the same as the baseline carbon stock in the same period $(t=0)$.

\subsubsection{Calculation of Carbon Stock in Aboveground Biomass}

Analogous to the calculation of the baseline reference scenario, to calculate the carbon stock in living biomass above ground, must be considered stratum $i$, which comes to every geographic area of the project implementation. In the case of this research project is regarded only 1 stratum of 1000 hectares.

$$
N_{A(t)}=T_{i(t) i} * 0.5
$$

Where:

The $N_{(t) i}=$ carbon stocks in above-ground biomass in the year (time) $t$ when the deployed project, expressed in $\mathrm{t}$ $\mathrm{C} /$ ha (tons of carbon per hectare);

$T_{(t) i}=$ above-ground biomass in the year (time) $t$ when the deployed project, expressed in $\mathrm{t} \mathrm{dm} / \mathrm{ha}$ (tons of dry matter per hectare);

$0.5=$ carbon fraction of dry matter expressed in $\mathrm{t} \mathrm{C/t} \mathrm{dm} \mathrm{(percentage).}$

EMBRAPA (2002) in its methodology for estimating carbon stocks in trees, considers various land uses. In their study, Renner (2004) was used a methodology for calculating living biomass above and below ground, set by the Federal University of Paraná (UFPR) for tree species Pinus taeda, which resembles much as the eucalyptus Table 14.

Table 14. Biomass equations adjusted for Pinus taeda UFPR

\begin{tabular}{cccc}
\hline & & \multicolumn{2}{c}{ Ratios } \\
\hline Compartment & Equation & $\mathrm{a}$ & $\mathrm{b}$ \\
\hline PFV & & 0,0595 & 0,9279 \\
PFVI & & 0,0012 & 1,0480 \\
PFGV & $\mathrm{a}\left(\mathrm{DAP}^{2} \mathrm{H}\right)^{\mathrm{b}}$ & 0,0001 & 1,3922 \\
PVR & & 0,4484 & 0,5619 \\
\hline
\end{tabular}

Source: UFPR; ECOPLAN (2003, apud RENNER, 2004, p. 59).

Where: PVF: Weight Verde de Fuste; PVFl: Weight Green Leaves; PVGv: Weight Green Living Branches; PVR: Weight Green Roots; dbh: diameter, H: height

In continuation, the author presents the results of calculating the amount of carbon individually, here represented by Table 15 . The result of these equations are expressed in $\mathrm{C} /$ ha (tons of carbon per hectare). 
Table 15. Equations for obtaining the amount of carbon in the compartments for individual trees

\begin{tabular}{cc}
\hline Compartment & Equation \\
\hline Shaft & $\mathrm{PCF}=0,1737 * \mathrm{PVF}$ \\
Leaves & $\mathrm{PCFl}=0,1422 * \mathrm{PVFl}$ \\
Living branches & $\mathrm{PCGv}=0,1595 * \mathrm{PVGv}$ \\
Root & $\mathrm{PCR}=0,1676 * \mathrm{PVR}$ \\
\hline
\end{tabular}

Source: UFPR; ECOPLAN (2003, apud RENNER, 2004, p 60).

Where: PCF: Weight in Carbon Fuste; PCFl: Weight of Carbon in Leaves; PCGv: Weight of Carbon in Living Branches; PVF: Weight Verde de Fuste; PVFl: Weight Green Leaves; PVGv: Weight Green Living Branches; PVR: Weight Green Roots, PCR Weight Carbon in Root.

Note: Values are expressed in t C/ha (tons of carbon per hectare).

These equations allow us to estimate the carbon fixed up below ground by the implementation of the project.

The software SisPinus in his prognosis, presents the results of production expressed in cubic meters. The author reports that in a reference to his research, industry Klabin, believes that wood $1 \mathrm{~m}$ equals 1 tonne mass.

She continues with the statement ROCK (2003, apud RENNER, 2004, p. 60), where a ton of carbon, the unit used by the carbon market, equivalent to 3.67 tons of $\mathrm{CO}_{2}$, which means that in reverse situation, a ton of $\mathrm{CO}_{2}$ equivalent to 0.27 tonnes of carbon. This information will be used for the subsequent calculation of REC.

Thus, in Table 16 is presents the amount of carbon estimated by summing compartments trunk, branches, foliage and roots for planting eucalyptus in the hypothesis of the research in years 7,14 and 21 , and these dates immediately before cuts.

Table 16. Fixed amount of carbon per hectare, prognosis based on lifelong project

\begin{tabular}{cccccc}
\hline & period & $\begin{array}{c}\text { Total } \\
\text { volume } \\
\text { of wood } \\
\text { produced } \\
\left(\mathrm{m}^{3}\right)\end{array}$ & $\begin{array}{c}\text { Amount of } \\
\text { Carbon } \\
(\mathrm{t} / \mathrm{ha})\end{array}$ & $\begin{array}{c}\text { Qty. Carbon } \\
\text { in } \\
65 \text { ha }(\mathrm{t})\end{array}$ & $\begin{array}{c}\text { Qty. Carbon } \\
\text { in 1000 ha (t) }\end{array}$ \\
\hline First Cutting & $7^{\text {th }}$ year & 434,2 & 43,70 & 2840,5 & 43700 \\
Second Cutting & $14^{\text {th }}$ year & 434,2 & 43,70 & 2840,5 & 43700 \\
Final Cutting & $21^{\text {st }}$ year & 434,2 & 43,70 & 2840,5 & 43700 \\
\hline
\end{tabular}

The prognosis in SisPinus calculated immediately after the first cut the amount of carbon fixed remaining $15 \%$ is in reference to the volume produced, this carbon associated with the existence of roots of trees.

Table 17 shows the evolution of tree growth and the amount of carbon fixed compartments corresponding to the stem, branches, leaves and roots, which is the baseline carbon fixed for the duration of the project.

In the year of implementation of the reforestation project, as directed by the methodology, the amount of carbon fixed equals before the implementation of the project. 
Table 17. Evolution of growth of trees and baseline amount of carbon fixed

\begin{tabular}{ccccccccc}
\hline & First Cutting & \multicolumn{3}{c}{ Second Cutting } & \multicolumn{3}{c}{ Final Cutting } \\
\hline Year & $\begin{array}{c}\text { Timber } \\
\text { volume in } \\
\text { m3/ha }\end{array}$ & $\begin{array}{c}\text { Fixed } \\
\text { carbon in } \\
\text { tC/há }\end{array}$ & $\begin{array}{c}\text { Timber } \\
\text { volume in } \\
\text { m3/ha }\end{array}$ & $\begin{array}{c}\text { Fixed } \\
\text { carbon in } \\
\text { tC/há }\end{array}$ & $\begin{array}{c}\text { Timber } \\
\text { Year } \\
\text { volume in } \\
\text { m3/ha }\end{array}$ & $\begin{array}{c}\text { Fixed } \\
\text { carbon in } \\
\text { tC/há }\end{array}$ \\
\hline 1 & 3,00 & 0,30 & 8 & 65,13 & 6,55 & 15 & 65,13 & 6,55 \\
2 & 45,90 & 4,62 & 9 & 87,99 & 8,85 & 16 & 87,99 & 8,85 \\
3 & 122,00 & 12,27 & 10 & 145,00 & 14,59 & 17 & 145,00 & 14,59 \\
4 & 206,10 & 20,73 & 11 & 206,10 & 20,73 & 18 & 206,10 & 20,73 \\
5 & 288,00 & 28,97 & 12 & 288,00 & 28,97 & 19 & 288,00 & 28,97 \\
6 & 364,30 & 36,65 & 13 & 364,30 & 36,65 & 20 & 364,30 & 36,65 \\
7 & 434,20 & 43,68 & 14 & 434,20 & 43,68 & 21 & 434,20 & 43,68 \\
\hline
\end{tabular}

\subsubsection{Calculating the Carbon Leakage}

According to the methodology if project participants demonstrate that the activity of small-scale reforestation under the CDM concept does not result in displacement of activities or people, or not yet generates other activities that did not exist before incurring increased emission of greenhouse gases, the calculation to estimate leakage is not required.

Table 18 shows the calculation of leakage estimated for the project based on the methodology and predictions generated from timber volume.

Table 18. Estimated trail regarding baseline amount of carbon fixed

\begin{tabular}{cccc}
\hline Year & Timber volume in $\mathrm{m}^{3} / \mathrm{ha}$ & $\Delta \mathrm{C}_{\mathrm{ACTUAL}}$ & $\Delta \mathrm{C}_{\mathrm{ACTUAL}}{ }^{*} 0.15$ \\
\hline 0 & 0,00 & 0,00 & 0,00 \\
1 & 3,00 & 1,11 & 0,61 \\
2 & 45,90 & 16,93 & 9,31 \\
3 & 122,00 & 44,99 & 24,74 \\
4 & 206,10 & 76,01 & 41,80 \\
5 & 288,00 & 106,21 & 58,41 \\
6 & 364,30 & 134,35 & 73,88 \\
7 & 434,20 & 160,13 & 88,06 \\
8 & 65,13 & 24,02 & 13,21 \\
9 & 87,99 & 32,45 & 17,84 \\
10 & 145,00 & 53,48 & 29,41 \\
11 & 206,10 & 76,01 & 41,80 \\
12 & 288,00 & 106,21 & 58,41 \\
13 & 364,30 & 134,35 & 73,88 \\
14 & 434,20 & 160,13 & 88,06 \\
15 & 65,13 & 24,02 & 13,21 \\
16 & 87,99 & 32,45 & 17,84 \\
17 & 145,00 & 53,48 & 29,41 \\
18 & 206,10 & 76,01 & 41,80 \\
19 & 288,00 & 106,21 & 58,41 \\
20 & 364,30 & 134,35 & 73,88 \\
21 & 434,20 & 160,13 & 88,06 \\
\hline
\end{tabular}




\subsubsection{Anthropogenic GHG Removals by Sinks}

The net GHG removals by sinks for each year of the first period carbon credit is calculated according to the equation below:

$$
E R_{A R C D M, t}=\Delta C_{P R O J, t}-\Delta C_{B S L, t}-G H G_{P R O J, t}-L_{t}
$$

Where:

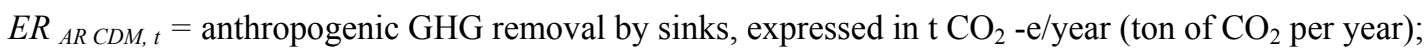

PROJ $\Delta_{C, t}=$ projected GHG removal by sinks at time $t$, expressed in $\mathrm{CO}_{2}$-e/year (ton of $\mathrm{CO}_{2}$ per year);

${ }_{B S L} \Delta_{C, t}=$ Baseline GHG removal by sinks, expressed in $\mathrm{CO}_{2}$-e/year (ton of $\mathrm{CO}_{2}$ per year);

$G H G_{P R O J, t}=\mathrm{GHG}$ emissions of the project, expressed in $\mathrm{CO}_{2}$-e/year $\mathrm{t}$ (tonne of $\mathrm{CO}_{2}$ per year);

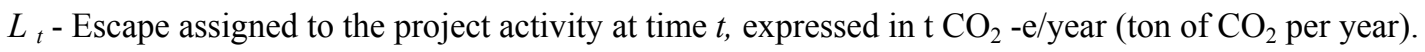

Given the chance to replace a pasture area, which emits a certain amount of greenhouse gases, methane in this case, as item 4. 3.1.3 of this research, the reforested area there will be no creation of food. Thus, the emission of greenhouse gases is not considered in this project.

The result of the Certified Emission Reduction (REC) in year $t_{v}$ was assumed that the check is given by the following equation:

$$
{ }_{t C E R}\left(t_{v}\right)=\sum_{t=0}^{T V}{ }^{E R} A R \quad C D M \Delta_{t} * t
$$

Where:

$t C E R_{(t v)}$ - $^{-}$Temporary Certified Emission Reductions in the year that the scan was taken;

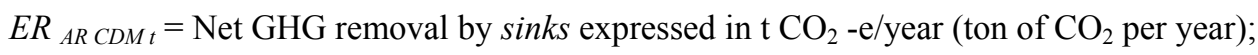

$t_{v}$ - Year that was assumed to verification;

$\Delta t$ - Increment of time (1 year).

Thus, Table 19 represents the result year-on-year reduction of emissions, the amount of carbon captured at the end of each cycle forest per hectare and the total amount of carbon captured at the end of the 21 years of the project, also per hectare. Table 20 is shown the amount of carbon sequestered in a forest and 65 ha of forest in a 1000 HA.

Table 19. Results of calculation for certified emission reduction project

\begin{tabular}{cccccc}
\hline & $\begin{array}{c}\text { Timber } \\
\text { volume in }\end{array}$ & \multicolumn{5}{c}{$\begin{array}{c}\Delta \text { CACTUAL } \\
* 0,15 \\
\text { Year }\end{array}$} & $\mathrm{m}^{3} /$ ha & $\Delta \mathrm{C}_{\text {ACTUAL }}$ & (escape) & ER $_{\text {AR CDM }}$ & \\
\hline 0 & 0,00 & 0,00 & 0,00 & 0,00 & \\
1 & 3,00 & 1,11 & 0,17 & 0,94 & \\
2 & 45,90 & 16,93 & 2,54 & 14,39 & \\
3 & 122,00 & 44,99 & 6,75 & 38,24 & \\
4 & 206,10 & 76,01 & 11,40 & 64,61 & \\
5 & 288,00 & 106,21 & 15,93 & 90,28 & \\
6 & 364,30 & 134,35 & 20,15 & 114,20 & \\
7 & 434,20 & 160,13 & 24,02 & 136,11 & $458.77 \mathrm{t}$ \\
& & & & Subtotal & $\mathrm{CO}_{2} /$ ha \\
& & & & $-->$ & end of the \\
& 65,13 & 24,02 & 3,60 & 20,42 & forest cycle \\
\hline
\end{tabular}




\begin{tabular}{|c|c|c|c|c|c|}
\hline 9 & 87,99 & 32,45 & 4,87 & 27,58 & \\
\hline 10 & 145,00 & 53,48 & 8,02 & 45,45 & \\
\hline 11 & 206,10 & 76,01 & 11,40 & 64,61 & \\
\hline 12 & 288,00 & 106,21 & 15,93 & 90,28 & \\
\hline 13 & 364,30 & 134,35 & 20,15 & 114,20 & \\
\hline \multirow[t]{2}{*}{14} & 434,20 & 160,13 & 24,02 & 136,11 & $498.65 \mathrm{t}$ \\
\hline & & & & $\begin{array}{c}\text { Subtotal } \\
-->\end{array}$ & $\begin{array}{c}\mathrm{CO}_{2} / \text { ha end } \\
\text { of the }\end{array}$ \\
\hline 15 & 65,13 & 24,02 & 3,60 & 20,42 & forest cycle \\
\hline 16 & 87,99 & 32,45 & 4,87 & 27,58 & \\
\hline 17 & 145,00 & 53,48 & 8,02 & 45,45 & \\
\hline 18 & 206,10 & 76,01 & 11,40 & 64,61 & \\
\hline 19 & 288,00 & 106,21 & 15,93 & 90,28 & \\
\hline 20 & 364,30 & 134,35 & 20,15 & 114,20 & \\
\hline \multirow[t]{7}{*}{21} & 434,20 & 160,13 & 24,02 & 136,11 & \\
\hline & & & & Subtotal & \\
\hline & & & & $-->$ & $498.65 \mathrm{t}$ \\
\hline & & & & & $\mathrm{CO}_{2} / \mathrm{ha}$ end \\
\hline & & & & & of the \\
\hline & & & & & forest cycle \\
\hline & & & tal: & 1456,10 & $\mathrm{tCO}_{2} / \mathrm{ha}$ \\
\hline
\end{tabular}

Source: Adapted from RENNER, 2004 and survey data.

Table 20. Estimated carbon cycle captured by the two simulations forest area to be reforested

\begin{tabular}{cccc}
\hline & Area (ha) & $\begin{array}{c}\text { Amount of } \\
\text { carbon } \\
\text { captured per } \\
\text { hectare for each } \\
\text { forest cycle } \\
\left(\mathrm{t} \mathrm{CO}_{2} / \text { ha }\right)\end{array}$ & $\begin{array}{c}\text { Total amount } \\
\text { of carbon } \\
\text { captured by } \\
\text { forest cycle } \\
\text { on each farm } \\
\left(\mathrm{t} \mathrm{CO}_{2}\right)\end{array}$ \\
\hline $1^{\text {st }}$ Forest cycle & 65 & 458,77 & 29820,05 \\
$2^{\text {nd }}$ Forest cycle & 1000 & 458,77 & 458770,00 \\
$3^{\text {rd }}$ Forest cycle & 65 & 498,65 & 32412,25 \\
& 1000 & 498,65 & 498650,00 \\
\hline
\end{tabular}

\subsubsection{Monitoring Plan (ex post)}

In this part of research that are treated the details of the monitoring plan of the CDM project. This monitoring plan basically performs checks throughout the duration of the project based on what was planned and considered for making the baselines.

\subsubsection{Estimate (ex post) Baseline GHG Removal by Sinks}

The method orients it is not necessary to monitor the baseline. The Baseline GHG Removal by Sinks will be the same as defined in section 4.3 .13 of this research. 


\subsubsection{Estimate (ex post) of GHG Removal by Sink}

The equation below shows the calculation of carbon stock to be used in monitoring.

$$
P_{(t)}=\sum_{i=1}^{I}\left(P_{A(t) i}+P_{B(t) i}\right) * A_{i} *(44 / 12)
$$

Where:

$P_{(t)}=$ the carbon stock in living biomass in the project region at time $(\mathrm{t})$ in the project activity, expressed in ${ }_{\mathrm{tCO}} \mathrm{e}$ (tonnes of carbon dioxide);

The $P_{(t)}={ }_{i}$ is the carbon stock of above-ground biomass at time $(t)$ of the stratum $(i)$ the project activity, expressed in $\mathrm{t} \mathrm{C} / \mathrm{ha}$ (tons of carbon per hectare);

$P_{B(t)}={ }_{i}$ is the stock of biomass carbon underground in time ( $\mathrm{t}$ ) of the stratum;

(I) the project activity, expressed in $\mathrm{t} \mathrm{C} / \mathrm{ha}$ (tons of carbon per hectare);

$A_{(i)}=$ Area of stratum design expressed in ha (hectares);

$i=$ stratum i ( $\mathrm{i}=$ total amount of strata).

4.3.12 Measuring Above Ground Biomass

$$
P_{A(t)}=E_{i(t) i} * 0.5
$$

Where:

The $P_{(t) i}=$ carbon stocks in above-ground biomass in the year (time) $t$ when the project activity, expressed in $\mathrm{t} \mathrm{C} /$ ha (tons of carbon per hectare);

$E_{(t) i}=$ aboveground biomass estimated in the year (time) $t$ when the project activity, expressed in $\mathrm{t} \mathrm{dm} / \mathrm{ha}$ (tons of dry matter per hectare);

$0.5=$ carbon fraction of dry matter expressed in $\mathrm{t} \mathrm{C} / \mathrm{t} \mathrm{dm}$ (tonne of carbon per tonne of dry matter).

To perform the estimation of aboveground biomass the following steps should be followed:

- Step 1 - Establish permanent plots and document analysis of their locations in the first monitoring report;

- Step 2 - Measure the diameter at breast height (DBH) and tree height and documented in the report;

- Step 3 - To estimate the aboveground biomass using equations developed or adapted locally or nationally.

4.3.13 Measurement of Biomass Below Ground

$$
P_{B(t)}=E_{i(t)} * R_{i} * 0.5
$$

Where:

$P_{B(t) i}=$ Carbon stock in living biomass below ground in the year (time) $t$ in the project activity, expressed in $\mathrm{t} C$ ha (tons of carbon per hectare);

$E_{(t) i}=$ estimate of underground biomass year (time) $t$ of the project activity, expressed in $\mathrm{t} \mathrm{dm} /$ ha (tons of dry matter per hectare);

$R=$ ratio of mass of the tree and root mass $(\mathrm{t} \mathrm{dm} / \mathrm{t} \mathrm{dm})$;

$0.5=$ carbon fraction of dry matter.

It is driven methodology that values locally or regionally adapted to be used for this estimate.

4.3.14 Estimate (ex post) of Carbon Leakage

To estimate carbon leakage, you should monitor each of the following indicators during the first crediting period:

- Area in crops within the project boundary displaced due to there project activity;

- Number of animals that utilize pasture within the project boundary that have been displaced due to the project activity;

- Number of animals and volume of forage intake per animal per hectare that were brought to the project area.

As this activity of small-scale reforestation under the CDM concept does not result in displacement of activities or people, or not yet generates other activities that did not exist before incurring increased emission of 
greenhouse gases, the calculation to estimate the leakage is not required.

$$
{ }_{T v} L=0
$$

Where:

$L_{t v}=$ Leakage attributable to the project activity at time $\mathrm{t}$, expressed in $\mathrm{CO}_{2}$-e/ano $\mathrm{t}$ (tonne of $\mathrm{CO}_{2}$ per year)

4.3.15 Estimate (ex post) Removal of Anthropogenic GHG at Sinkhole

Removal of anthropogenic greenhouse gas sink occurs at the designed result of removing less the baseline carbon fixed, less leakage. The resulting value of REC in the year the check is given as follows:

$$
\operatorname{tCER}_{\left(t_{V}\right)}=\sum_{t=0}^{T V} P_{(t)}-\sum\left(_{G H G} \operatorname{PROJ},(t)-\Delta C_{B S L}, t\right)-L_{t V}
$$

Where:

${ }_{t C E R_{(t)}}=$ Certified Emission Reduction in year $t$ the duration of the project;

$P(t)=$ Inventory of carbon calculated for the proximity of the project in year $t$ the duration of the project,

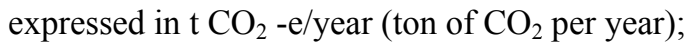

$G H G_{P R O J,(t)}=\mathrm{GHG}$ emissions of the project, expressed in $\mathrm{CO}_{2}$-e/ year $\mathrm{t}$ (tonne of $\mathrm{CO}_{2}$ per year);

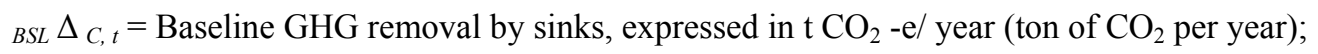

$L_{t v}=$ Leakage attributable to the project activity at time $t$ scan, expressed as $\mathrm{CO}_{2}$-e/ year $\mathrm{t}$ (tonne of $\mathrm{CO}_{2}$ per year);

$t_{v}$ - Year of the verification.

All these equations are applied in the monitoring stage, part of the CDM project upon its implementation, therefore not applicable in this research project. However, spreadsheets monitoring should be made considering these calculations and parameters.

\section{Analysis and Evaluation of Results}

In the previous chapter, were made in the amounts raised beef cattle and milk for the 65 ha property in Conceição de Macabu. The data analysis was based on information from four months of production and operation of the farm. From those data, Table 21 shows the forecast annual cash flow of the farm without considering depreciation, so it can be compared with the results of the NPV of culture eucalyptus, conducted year-on-year.

By calculation presented in Table 8, the average annual income derived from the operation of livestock in the region studied without considering the depreciation of $\mathrm{R} \$ 176,763.30$ and then the monthly income of $\mathrm{R}$ $\$ 14,730,28$.For the same scenario, considering depreciation, the average annual income is $\$ 147.209 .34$ and monthly income of $\mathrm{R} \$ 12,267.45$.

Timber production of $434.2 \mathrm{~m}^{3} / \mathrm{ha}$ at the end of each cycle forestry, informed the prognosis of SisEucalipto, served as input to calculate the revenue from the sale of the stereo to produce coking coal, whose value is shown in Table 21 to below. 
Table 21. Forecast values obtained in stereo commercialization of eucalyptus for metallurgical coal production

\begin{tabular}{cccccc}
\hline & $\begin{array}{c}\text { Volume } \\
\text { produced } \\
\text { by 7-year } \\
\text { forest } \\
\text { cycle } \\
\begin{array}{c}\text { Production and } \\
\text { income }\end{array}\end{array}$ & $\begin{array}{c}\text { Stere Value } \\
\text { (Value } \\
\text { provided } \\
\text { by CEPEA) }\end{array}$ & $\begin{array}{c}\text { Estimated } \\
\text { revenue per } \\
\text { hectare }\end{array}$ & $\begin{array}{c}\text { Revenue generated } \\
\text { by forest cycle } \\
\text { (65ha of forest) }\end{array}$ & $\begin{array}{c}\text { Revenue generated } \\
\text { by forest cycle } \\
\text { (1000ha forest) }\end{array}$ \\
\hline $\begin{array}{c}\text { Stere value } \\
\text { (supplied by } \\
\text { CEPEA) }\end{array}$ & 434,2 & $\mathrm{R} \$ 50,00$ & $\mathrm{R} \$ 21.710,00$ & $\mathrm{R} \$ 1.411 .150,00$ & $\mathrm{R} \$ 21.710 .000,00$ \\
$\begin{array}{c}\text { Stere value } \\
\text { (suggested by }\end{array}$ & 434,2 & $\mathrm{R} \$ 20,00$ & $\mathrm{R} \$ 8.684,00$ & $\mathrm{R} \$ 564.460,00$ & $\mathrm{R} \$ 8.684 .000,00$ \\
ArcellorMittal) & & & & & \\
\hline
\end{tabular}

To conduct a feasibility analysis of the project, mathematical equations were used-financial, which started from a baseline projections and statistical basis, with simulations.

\subsection{Net Present Value (NPV) without Carbon Credits}

Through the analysis of results provided by VPL, you can identify whether the project is economically viable or not. If NPV is zero, the cash flows from the investment are all consumed to pay the cost of the capital invested. If NPV is positive, the result from the project covers the debt acquired to invest in the project and the rate of return determined by investors. Therefore, search is always a project that has positive NPV (NETO, 2006).

\subsection{Calculation for 65ha Area and Value-Based CEPEA}

Tables 22, 23 and 24 are the cash flows and NPV calculated for planting and felling eucalyptus charcoal to market the area to $65 \mathrm{ha}$, the three cycles forest, considering the amount of stereo $\$ 50.00$, suggested by CEPEA, and annual discount rate of $10 \%$.

Table 22. Calculated NPV of the first cycle of eucalyptus forest for culture 65 ha in area, with a value of $\$ 50.00$ stereo

\begin{tabular}{|c|c|c|c|c|c|c|c|c|}
\hline & \multicolumn{8}{|c|}{ First Forest Cycle } \\
\hline & Year 1 & Year 2 & Year 3 & Year 4 & Year 5 & Year & & Year 7 \\
\hline \multicolumn{9}{|c|}{ Eucalyptus Planting } \\
\hline Total Cost & $\mathrm{R} \$ 77.949,00$ & $\mathrm{R} \$ 20.250,00$ & $\mathrm{R} \$ 18.900,00$ & $\mathrm{R} \$ 17.550,00$ & $\mathrm{R} \$$ - & $\mathrm{R} \$$ & - & $\mathrm{R} \$$ \\
\hline \multicolumn{9}{|l|}{ Total Revenue } \\
\hline \multirow[t]{4}{*}{ Cash Flow } & -R\$ 77.949,00 & $-R \$ 20.250,00$ & $-\mathrm{R} \$ 18.900,00$ & $-\mathrm{R} \$ 17.550,00$ & $\mathrm{R} \$$ - & $\mathrm{R} \$$ & - & $\mathrm{R} \$ 1.411 .150,00$ \\
\hline & & & & & & $\begin{array}{r}\text { Euca } \\
\mathrm{Cy}\end{array}$ & $\begin{array}{l}\text { lyptus 1st } \\
\text { le NAV }\end{array}$ & $\mathrm{R} \$ 610.358,08$ \\
\hline & & & & & & Ann & ual NAV & $\mathrm{R} \$ 87.194,01$ \\
\hline & & & & & & Mon & thly NAV & $\mathrm{R} \$ 7.266,17$ \\
\hline
\end{tabular}


Table 23. Calculated NPV of the second cycle of eucalyptus forest for culture $65 \mathrm{ha}$ in area, with a value of $\$ 50.00$ stereo

\begin{tabular}{|c|c|c|c|c|c|c|c|c|}
\hline & \multicolumn{8}{|c|}{ Second Forest Cycle } \\
\hline & Year 8 & Year 9 & Year 10 & Year 11 & Year 12 & Yea & & Year 14 \\
\hline \multicolumn{9}{|c|}{ Eucalyptus Planting } \\
\hline Total Cost & $\mathrm{R} \$ 18.090,00$ & $\mathrm{R} \$ 14.850,00$ & $\mathrm{R} \$ 14.850,00$ & $\mathrm{R} \$ 14.850,00$ & $\mathrm{R} \$$ - & $\mathrm{R} \$$ & - & $\mathrm{R} \$$ \\
\hline Total Revenue & $\mathrm{R} \$ \quad-$ & $\mathrm{R} \$-$ & $\mathrm{R} \$ \quad-$ & $\mathrm{R} \$ \quad-$ & $\mathrm{R} \$-$ & $\mathrm{R} \$$ & - & $\mathrm{R} \$ 1.411 .150,00$ \\
\hline \multirow[t]{5}{*}{ Cash Flow } & $-\mathrm{R} \$ 18.090,00$ & $-\mathrm{R} \$ 14.850,00$ & $-\mathrm{R} \$ 14.850,00$ & $-\mathrm{R} \$ 14.850,00$ & $\mathrm{R} \$-$ & $\mathrm{R} \$$ & - & $\mathrm{R} \$ 1.411 .150,00$ \\
\hline & & & & & & \multicolumn{3}{|c|}{ Eucalyptus $2^{\text {nd }}$} \\
\hline & & & & & & \multicolumn{2}{|c|}{ Cycle NAV } & $\mathrm{R} \$ 674.125,12$ \\
\hline & & & & & & \multicolumn{2}{|c|}{ Annual NAV } & $\mathrm{R} \$ 96.303,59$ \\
\hline & & & & & & \multicolumn{2}{|c|}{ Monthly NAV } & $\mathrm{R} \$ \quad 8.025,30$ \\
\hline
\end{tabular}

Table 24. Calculated NPV of the third cycle forestry culture eucalyptus 65 ha in area, with a value of $\$ 50.00$ stereo

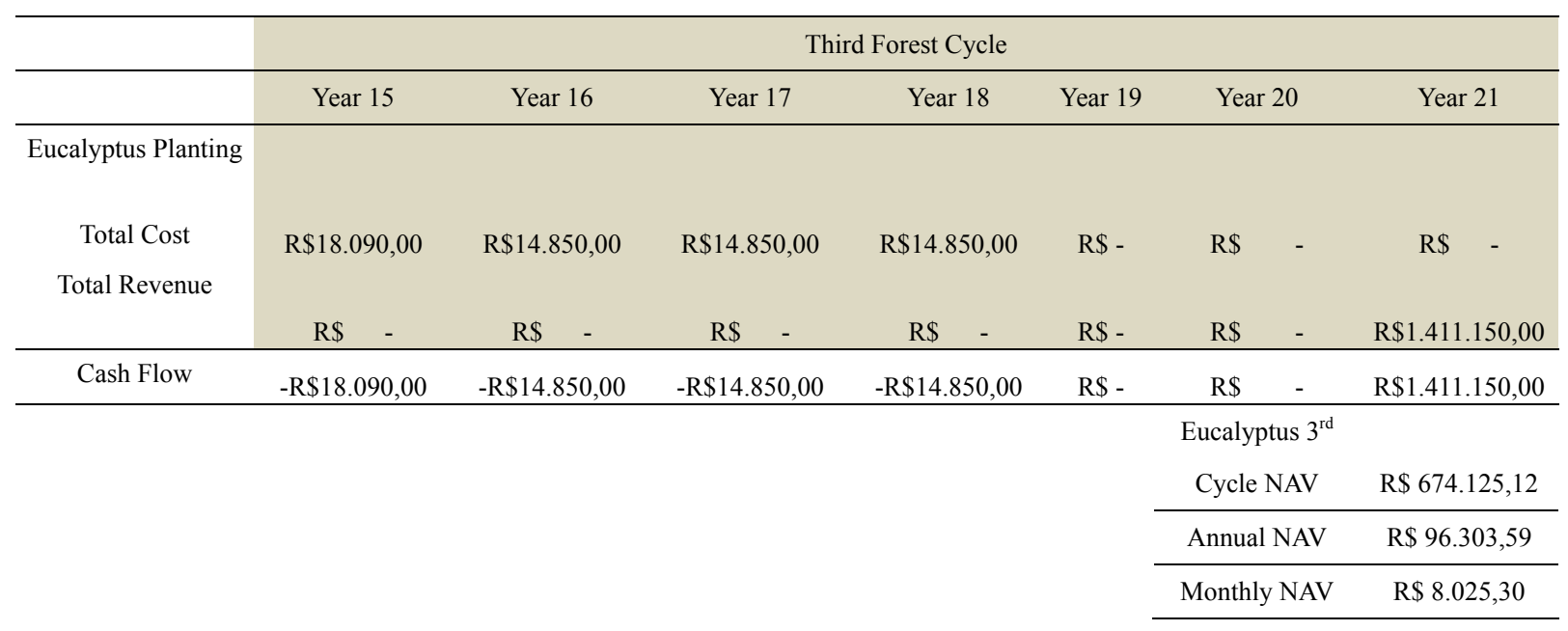

\subsection{Net Present Value (NPV) with Carbon Credits}

In this subchapter are the calculations considering the values of marketing ton of carbon captured in the two markets REC: Market regulated by the Kyoto Protocol, in the manner pre-2012 and average values applied, and the Voluntary Market. It is here that all revenue from the sale of each REC planned for 7 years is inputted the beginning of each forest cycle. In Table 25 are simulations of revenue earned through the sale of CERs estimated in Table 20 of the previous chapter, considering an average value of $\$ 20.00$ for the value and market price adjusted $\$ 3.10$ for the voluntary markets, as referenced in chapter 2 . The conversion rate used was U.S. $\$ 1.00=$ R \$ 2.09, extracted on 11/28/2012 Central Bank (Central Bank, 2012). 
Table 25. Projected revenue obtained through marketing REC

\begin{tabular}{|c|c|c|c|c|c|c|}
\hline & & $\begin{array}{c}\text { Value per } \\
\text { ton of } \\
\mathrm{CO}_{2} \\
(\mathrm{US} \$ / \text { Ton } \\
\mathrm{CO}_{2} \text { ) }\end{array}$ & $\begin{array}{c}\text { Area } \\
\text { (ha) }\end{array}$ & $\begin{array}{c}\text { Amount } \\
\text { of carbon } \\
\text { captured } \\
\text { per } \\
\text { hectare for } \\
\text { each } \\
\text { forest } \\
\text { cycle } \\
\text { (t CO} 2 / \text { ha) }\end{array}$ & $\begin{array}{c}\text { Expected value } \\
\text { per forest cycle } \\
\text { (US\$) }\end{array}$ & $\begin{array}{c}\text { Expected value per } \\
\text { forest cycle } \\
(\mathrm{R} \$)\end{array}$ \\
\hline \multirow{6}{*}{ Regulated Market } & \multirow{2}{*}{$1^{\text {st }}$ Forest cycle } & 20 & 65 & 458,77 & $\$ 596.401,00$ & $\mathrm{R} \$ 1.246 .478,09$ \\
\hline & & 20 & 1000 & 458,77 & $\$ 9.175 .400,00$ & $\mathrm{R} \$ 19.176 .586,00$ \\
\hline & \multirow{2}{*}{$2^{\text {nd }}$ Forest cycle } & 20 & 65 & 498,65 & $\$ 648.245,00$ & $\mathrm{R} \$ 1.354 .832,05$ \\
\hline & & 20 & 1000 & 498,65 & $\$ 9.973 .000,00$ & $\mathrm{R} \$ 20.843 .570,00$ \\
\hline & \multirow{2}{*}{$3^{\text {rd }}$ Forest cycle } & 20 & 65 & 498,65 & $\$ 648.245,00$ & $\mathrm{R} \$ 1.354 .832,05$ \\
\hline & & 20 & 1000 & 498,65 & $\$ 9.973 .000,00$ & $\mathrm{R} \$ 20.843 .570,00$ \\
\hline \multirow{6}{*}{ Voluntary Market } & \multirow{2}{*}{$1^{\text {st }}$ Forest cycle } & 3,1 & 65 & 458,77 & $\$ 92.442,16$ & $\mathrm{R} \$ 193.204,10$ \\
\hline & & 3,1 & 1000 & 458,77 & $\$ 1.422 .187,00$ & $\mathrm{R} \$ 2.972 .370,83$ \\
\hline & \multirow{2}{*}{$2^{\text {nd }}$ Forest cycle } & 3,1 & 65 & 498,65 & $\$ 100.477,98$ & R\$ 209.998,97 \\
\hline & & 3,1 & 1000 & 498,65 & $\$ 1.545 .815,00$ & $\mathrm{R} \$ 3.230 .753,35$ \\
\hline & \multirow{2}{*}{$3^{\text {rd }}$ Forest cycle } & 3,1 & 65 & 498,65 & $\$ 100.477,98$ & $\mathrm{R} \$ 209.998,97$ \\
\hline & & 3,1 & 1000 & 498,65 & $\$ 1.545 .815,00$ & $\mathrm{R} \$ 3.230 .753,35$ \\
\hline
\end{tabular}

\subsection{Calculation for 65ha Area, Value-Based CEPEA}

Table 26 are the cash flows and NPV calculated for planting and felling eucalyptus market charcoal to the area of 65 ha in the three cycles forest, considering the amount of stereo $\$ 50,00$, suggested by CEPEA, the annual discount rate of $10 \%$ and revenue from REC traded on Regulated Markets. This is the most optimistic scenario, since here applies the highest price per ton of carbon and also the highest value for the sale of stereo for the production of coking coal. 
Table 26. - NPV calculated in three cycles forest for culture eucalyptus 65 ha in area, with stereo value of $\$ 50.00$, and revenue from REC in the regulated market

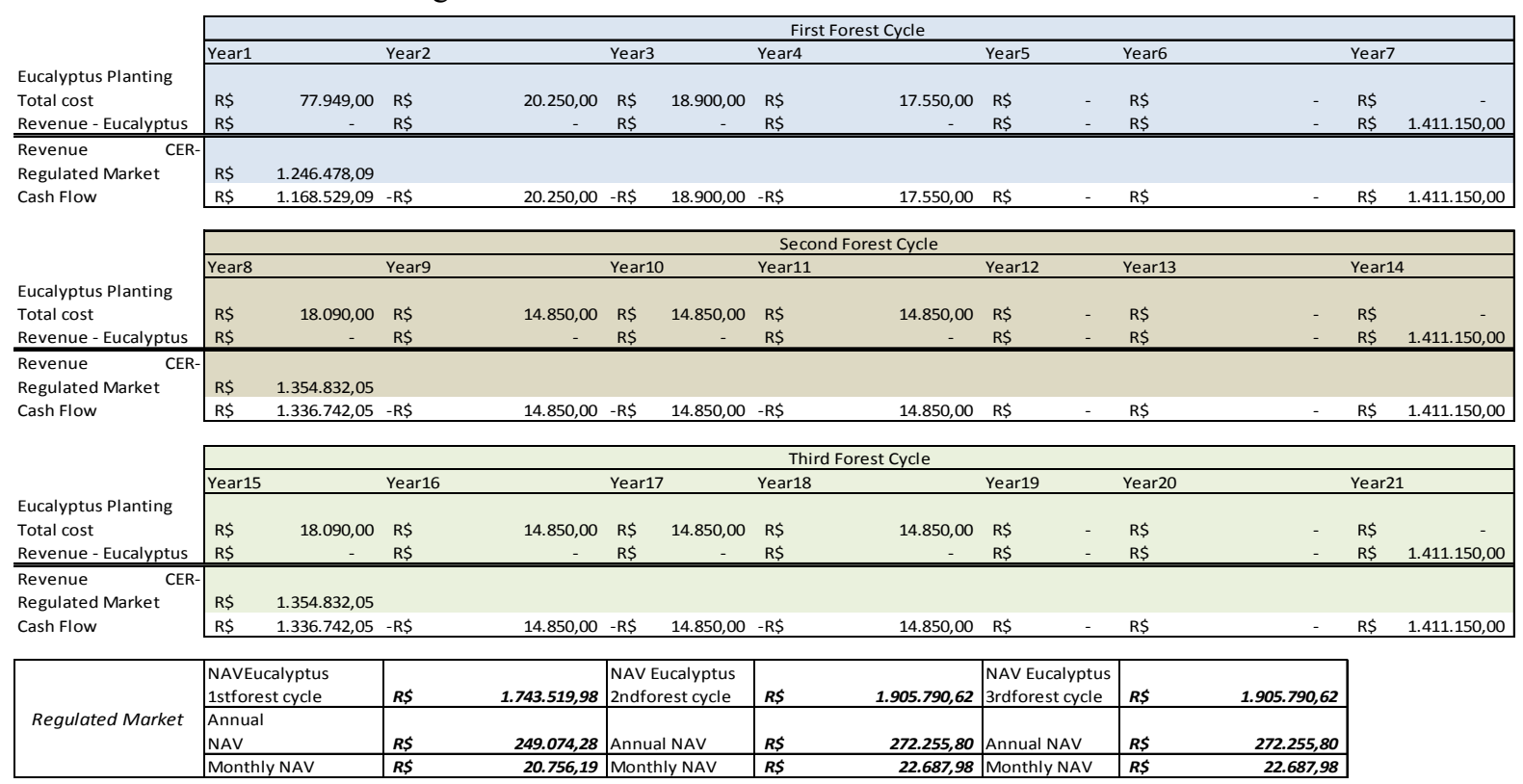

Table 27 are the cash flows and NPV calculated for planting and felling eucalyptus charcoal to market the area to $65 \mathrm{ha}$, the three cycles forest, considering the amount of stereo $\$ 50.00$, suggested by CEPEA, the annual discount rate of $10 \%$ and revenue from REC traded on voluntary markets.

Table 27. NPV calculated for the three cycles forest for culture eucalyptus 65 ha in area, with stereo value of $\$ 50.00$, and revenue in the voluntary market REC

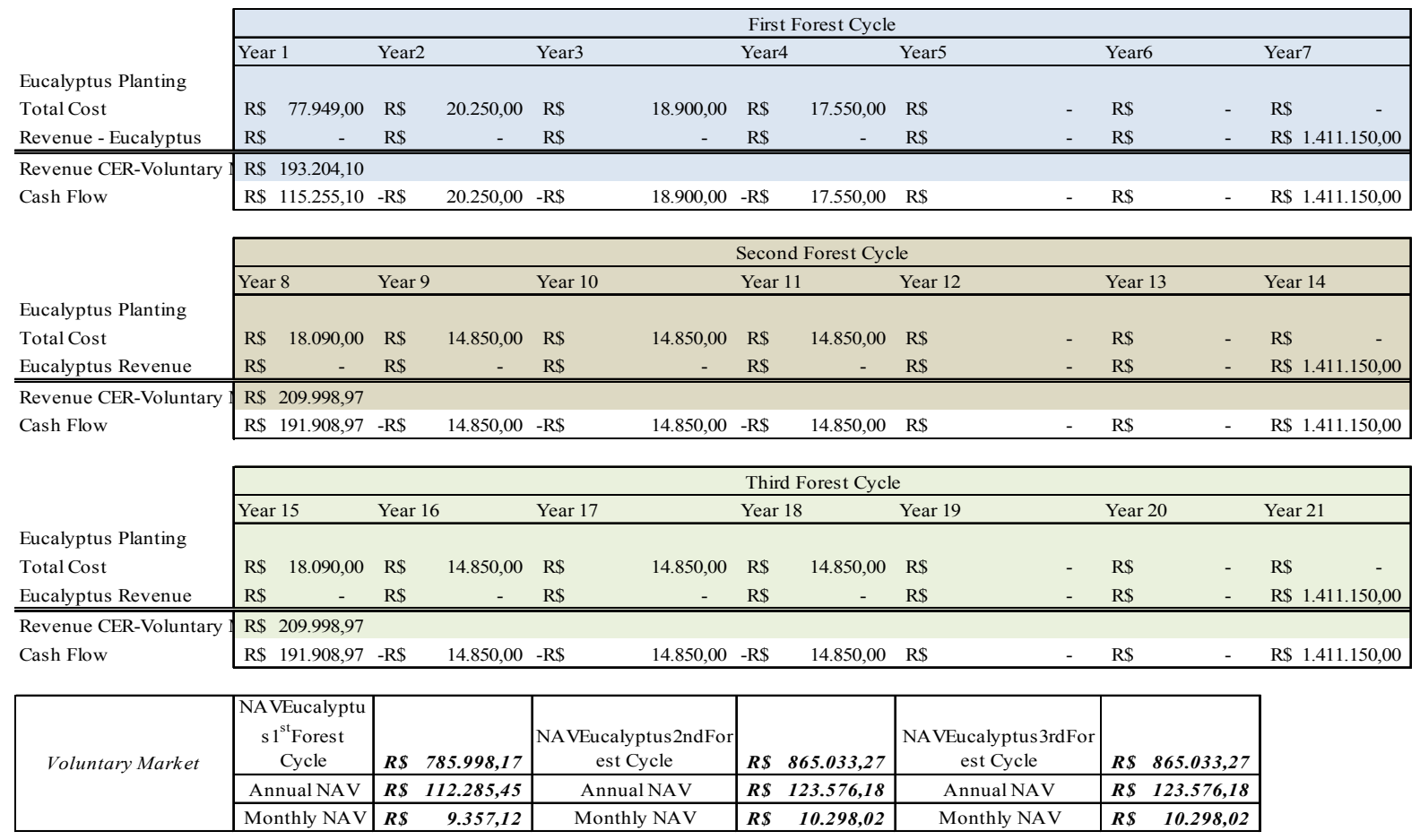

\subsection{Calculation for 65 ha Area and Value-Based Arcelor Mittal}

Table 28 are the cash flows and NPV calculated for planting and felling eucalyptus charcoal to market the area to 
65ha, the three cycles forest, considering the amount of stereo $\$ 20.00$, suggested by Arcelor Mittal, the annual discount rate of $10 \%$ and revenue from REC traded on Regulated Markets.

Table 28. NPV calculated in three cycles forest for culture eucalyptus 65 ha in area, with stereo value of $\$ 20.00$, and revenue from REC in the regulated market

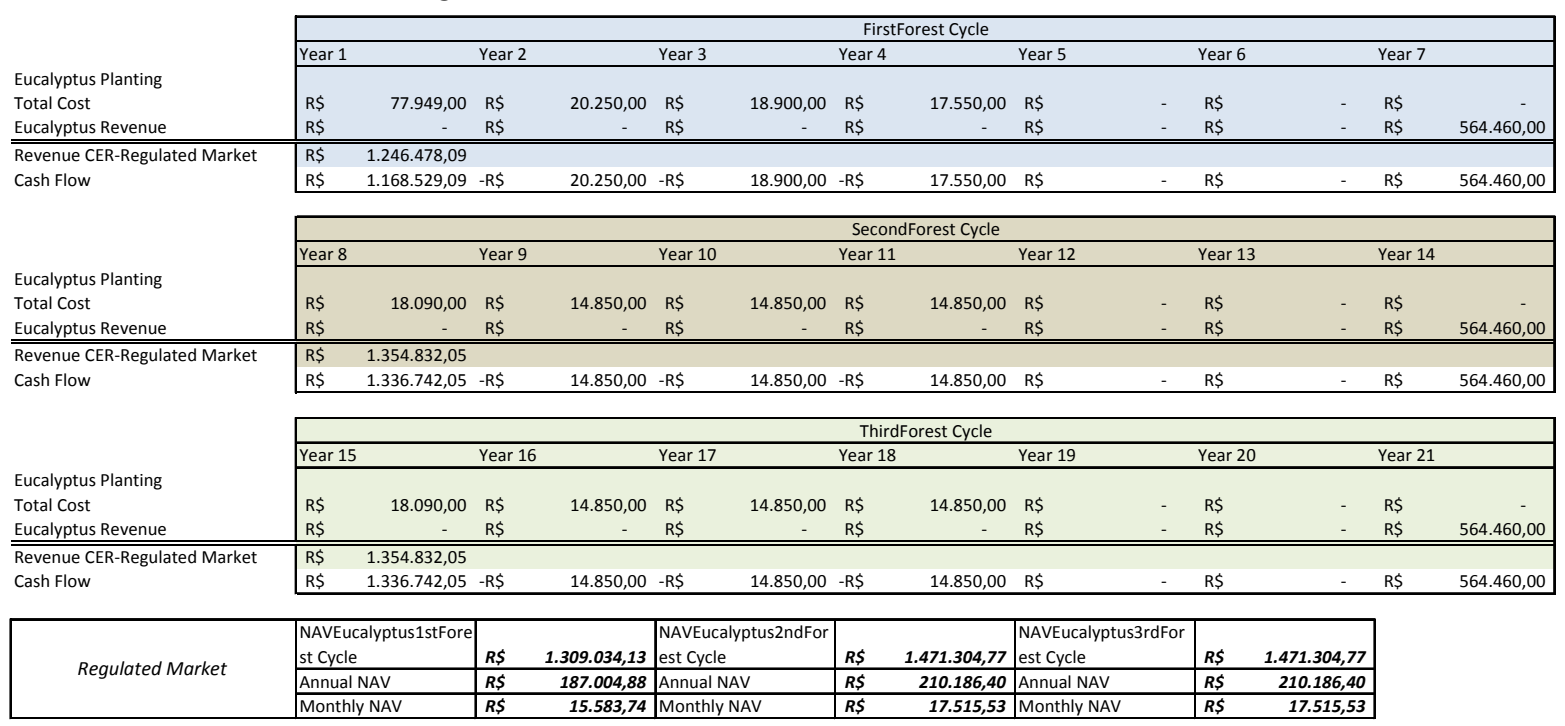

Table 29 are the cash flows and NPV calculated for planting and felling eucalyptus charcoal to market the area to $65 \mathrm{ha}$, the three cycles forest, considering the amount of stereo \$20.00, suggested by Arcelor Mittal, the annual discount rate of $10 \%$ and revenue from REC marketed in Voluntary Markets.

Table 29. NPV calculated in three cycles forest for culture eucalyptus 65 ha in area, with stereo value of $\$ 20.00$, and revenue in the Voluntary Market REC

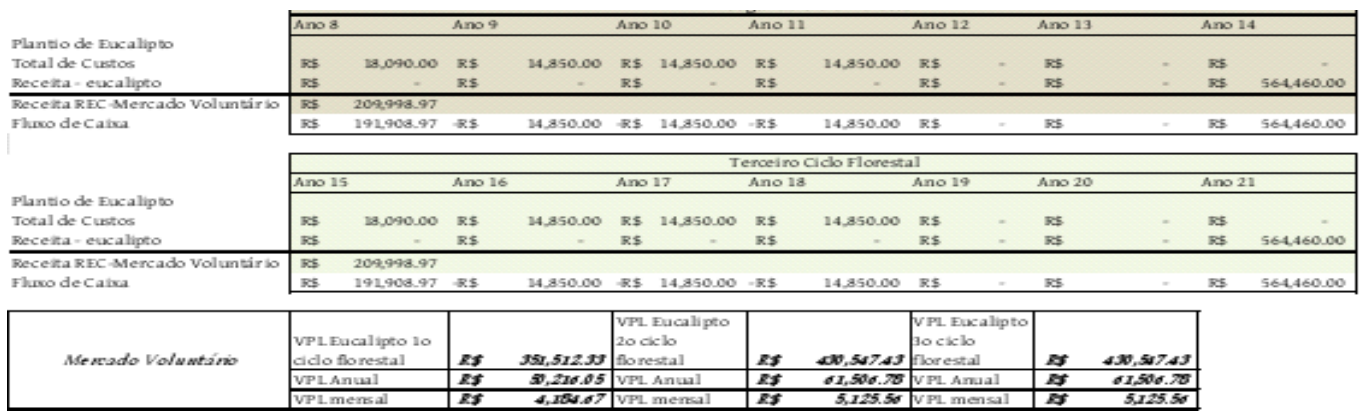

tabela 29

\begin{tabular}{|c|c|c|c|c|c|c|c|c|c|c|c|c|c|c|}
\hline \multirow{4}{*}{ Eucalyptus Planting } & & & & & & & & & & & & & & \\
\hline & \multicolumn{14}{|c|}{ FirstForest Cycle } \\
\hline & \multicolumn{2}{|l|}{ Year 1} & \multicolumn{2}{|l|}{ Year 2} & \multicolumn{2}{|l|}{ Year 3} & \multicolumn{2}{|c|}{ Year 4} & \multicolumn{2}{|l|}{ Year 5} & \multirow[t]{2}{*}{ Year 6} & \multicolumn{3}{|c|}{ Year 7} \\
\hline & & & & & & & & & & & & & & \\
\hline Total Cost & RS & $77,949.00$ & $\mathrm{R} \$$ & $20,250.00$ & $\mathrm{R} \$$ & $18,900.00$ & $\mathrm{R} \$$ & $17,550.00$ & $\mathrm{R} \$$ & - & RS & - & $\mathrm{R} \$$ & - \\
\hline Eucalyptus Revenue & $\mathrm{R} \$$ & - & $\mathrm{R} \$$ & - & $\mathrm{RS}$ & - & $\mathrm{R} \$$ & - & $\mathrm{RS}$ & - & $\mathrm{RS}$ & - & $\mathrm{R} \$$ & $564,460.00$ \\
\hline \multicolumn{15}{|c|}{$\begin{array}{ll}\text { Revenue } & \text { CER- }\end{array}$} \\
\hline \multirow{4}{*}{$\begin{array}{l}\text { Voluntary Market } \\
\text { Cash Flow }\end{array}$} & $\mathrm{R} \$$ & $193,204.10$ & & & & & & & & & & & & \\
\hline & $\mathrm{R} \$$ & $115,255.10$ & $-R \$$ & $20,250.00$ & $-\mathrm{R} \$$ & $18,900.00$ & $-\mathrm{R} \$$ & $17,550.00$ & $\mathrm{R} \$$ & - & $\mathrm{R} S$ & - & $\mathrm{R} \$$ & $564,460.00$ \\
\hline & \multicolumn{14}{|c|}{ SecondForest Cycle } \\
\hline & Year 8 & & Year 9 & & Year 10 & & Year 11 & & Year 12 & & Year 13 & & Year & \\
\hline \multicolumn{15}{|l|}{ Eucalyptus Planting } \\
\hline Total Cost & $\mathrm{R} \$$ & $18,090.00$ & $\mathrm{R} \$$ & $14,850.00$ & $\mathrm{R} \$$ & $14,850.00$ & $\mathrm{R} \$$ & $14,850.00$ & $\mathrm{RS}$ & - & RS & - & $\mathrm{R} \$$ & - \\
\hline Eucalyptus Revenue & $\mathrm{R} \$$ & - & $\mathrm{R} \$$ & - & $\mathrm{RS}$ & - & $\mathrm{R} \$$ & - & $\mathrm{RS}$ & - & $\mathrm{RS}$ & - & $\mathrm{R} S$ & $564,460.00$ \\
\hline \multirow{2}{*}{\multicolumn{15}{|c|}{$\begin{array}{l}\text { Revenue CER- } \\
\text { Voluntary Market } \quad \text { R\$ }\end{array}$}} \\
\hline & & & & & & & & & & & & & & \\
\hline Cash Flow & $\mathrm{R} \$$ & $191,908.97$ & $-\mathrm{R} \$$ & $14,850.00$ & $-\mathrm{R} \$$ & $14,850.00$ & $-\mathrm{RS}$ & $14,850.00$ & $\mathrm{R} S$ & - & $\mathrm{R} S$ & - & $\mathrm{R} \$$ & $564,460.00$ \\
\hline
\end{tabular}


This is the best scenario, since here applies the lower the price per ton of carbon and also the lowest value for the sale of stereo for the production of coking coal.

\subsection{Evaluating the Results Properly Said}

The calculations presented in the previous subchapter are considering 3 variables:

- Area for the planting of 65 ha or $1000 \mathrm{HA}$;

- Value stereo eucalyptus wood stand, with data from the CEPEA and Arcelor Mittal;

- Value applied to a ton of carbon captured in Regulated Markets and Voluntary.

Table 30 summarizes the analysis performed in this section.

Table 30. NPV calculated in three cycles forest for culture eucalyptus associate of the REC market planted on a 65 ha farm

\begin{tabular}{ccccc}
\hline & $\begin{array}{c}\text { Suggested } \\
\text { Stere value }\end{array}$ & $\begin{array}{c}\text { Monthly NAV 65ha } \\
\text { without REC }\end{array}$ & $\begin{array}{c}\text { Monthly NAV 65ha } \\
\text { withCER-Regulated Market }\end{array}$ & $\begin{array}{c}\text { Monthly NAV 65ha } \\
\text { withCER-Voluntary Market }\end{array}$ \\
\hline $\begin{array}{c}\text { CEPEA } \\
\text { Arcelor } \\
\text { Mittal }\end{array}$ & $\mathrm{R} \$ 50,00$ & $\mathrm{R} \$ 8.025,30$ & $\mathrm{R} \$ 22.687,98$ & $\mathrm{R} \$ 10.298,02$ \\
& $\mathrm{R} \$ 20,00$ & $\mathrm{R} \$ 2.852,85$ & $\mathrm{R} \$ 17.515,53$ & $\mathrm{R} \$ 5.125,56$ \\
\hline
\end{tabular}

Thus, the estimate is more economically aggressive to plant eucalyptus in order to market the production of coking coal, considering the price suggested by CEPEA stereo and sale of REC in the Regulated Market.

\section{Conclusion and Suggestion for New Research}

All calculations made show that all options resulting from combinations of the variables showed positive values of NPV. Eucalyptus plantations to meet demand for coking coal generation without considering the sale of REC, in itself shows a profitable operation.

Taking up by analyzing the different NPV results for each combination made for planting in the area of 65 ha, Table 30, compared with the average revenue of Table 21, divided into two studies:

- Average revenue livestock without considering the depreciation of $\mathrm{R} \$ 14,730.28$;

- Average revenue of ranching considering depreciation of $\mathrm{R} \$ 12,267.45$.

For both cases, only the planting of eucalyptus shows not bring economic advantage to that get with livestock, comparing cash flows. However, in adding up the revenues obtained by the sale of REC in the regulated markets of U.S. \$22,678.98 to U.S. \$ 17,515.53, which provides a considerably higher value in the sale of carbon credits compared to the voluntary markets, $\mathrm{R} \$ 10,298.02$ to $\mathrm{R} \$ 5,515.56$, brings an economic-financial advantage when adopting this strategy in increasing the income of small producers. In bringing up the revenue from the sale of REC start of each forest cycle, income is sufficient for the cultivation of livestock can be stopped without causing harm to the producer.

In considering the specific nature of this research, the following are some suggestions of related work that could increase knowledge about the subject studied here, such as expanding the model studied here researching up on creating a cooperative of producers of eucalyptus; study creation of an association of coal for generation of steel near the region studied; analyze the logistics network in the region and suggestions for new adaptations in various modes to meet the production flow of wood to the charcoal and charcoal production undertaken by steelmakers and finally find similar solutions outside Brazil so that we can assess whether the cultures of other countries use different criteria.

\section{References}

Açobrasil. (2009). Sustainability Report. São Paulo. Retrieved April 11, 2013, from http://www.acobrasil.org.br/site/portugues/sustentabilidade/downloads/Relatorio_2009.pdf

Aleixo. (2007). Change of Beneficiary Form and reoccupation of the Batch Settlement Chapel, Conception Macabu, $R J$ (Master thesis). Retrieved from 211F. Dissertation. Institute of Human and Social Sciences, Federal Rural University of Rio de Janeiro, Seropédica.

AMS-Mining Association of Forestry. (2005). Perspectives and Trends Wood Supply for the Forest-Based 
Industry in Brazil. Minas Gerais. Retrieved September 30, 2010, from http://www.silviminas.com.br/Publicacao/Arquivos/publicacao_131.pdf

Arcelor, M. (2008). Forestry Partners Program. Minas Gerais. Retrieved July 12, 2010, from http://www.arcelormittalbioenergia.com.br/index.asp?Grupo=2\&SubGrupo=9

Arnt, R. (2000). Sequestration legal. Exame, São Paulo: Editora Abril, 716, 99-106.

BACEN-Banco Central do Brasil. (2013). Currency Conversion. Retrieved from http://www4.bcb.gov.br/pec/conversao/conversao.asp

Bermann, C. (2002). Energy in Brazil: To what? For what? Crises and alternatives for a sustainable country. Rio de Janeiro: Physics Bookstore.

BNDES-National Bank for Economic and Social Development. (2002). The Clean Development Mechanism Guidance. Rio de Janeiro.

Booth, W. C., Colomb, G. G., \& Williams, J. M. (2008). The Craft of Research. USA: Chicago. http://dx.doi.org/10.7208/chicago/9780226062648.001.0001

Brito, O. J. (2013). Report on the Production Chain Charcoal in São Paulo. Retrieved April 11, 2013, from http://www.ipef.br/tecprodutos/procarvao/procarvao.pdf

CEPEA-Center for Advanced Studies in Applied Economics from USP. (2012). Forestry Bulletin. Retrieved November 26, 2012, from http://www.cepea.esalq.usp.br/florestal/files/2012/09set.pdf

CIDE-Foundation Centre for Information and Data in Rio de Janeiro. (2012). Data in Rio de Janeiro. Rio de Janeiro. Retrieved September 18, 2012, from http://www.cide.rj.gov.br

Colombo, S., Pepper, A. S., \& Hatakeyama, K. (2013). Charcoal Production in Cylindrical Vertical Furnaces: A Sustainable Model. Retrieved April 11, 2013, from http://www.simpep.feb.unesp.br/anais/anais_13/artigos/1208.pdf

Costa, F. P. (2009). Production Costs in Cattle. Retrieved November 17, 2009, from http://www.cnpgc.embrapa.br/publicacoes/cot/cot104/COT104.pdf

Demo, P. (1994). Research and Knowledge Building: Methods in Scientific Way of Habermas. Rio de Janeiro: Brazilian Time.

EMBRAPA-Brazilian Company of Support for Livestock and Agriculture. (2002). Macroprogram 1: Strategic Research Embrapa in Brazil. Brasília. Retrieved April 14, 2010, from http://www.macroprograma1.cnptia.embrapa.br/

Green, A. G., \& Unruh, J. D. (2010). Clean Development Mechanism Afforestation and Reforestation projects: implications for local agriculture. CAB Reviews: Perspectives in Agriculture, Veterinary Science, Nutrition and Natural Resources, 5.

Gunther, H. (2006). Qualitative research versus quantitative research: that is the question. Brasilia, 22(2). Retrieved 2010, from http://www.scielo.br/scielo.php?script=sci_arttext\&pid=S0102-37722006000200010\&lng=en\&nrm=iso

Hasenclever, L. (2005). Local development in the state of Rio de Janeiro: advanced studies in local realities. Rio de Janeiro: Editora e-papers.

Hasenclever, L., Faure, Y., \& Neto, R. S. (2003). Local economic development in the state of Rio de Janeiro: Four exploratory studies: Fields, Itaguaí, Macae and New Freiburg. Rio de Janeiro: Editora e-papers.

Indicators of Costs, Productivity, Income Credits and Carbon Plantations of Eucalyptus and Pinus in Small Rural Properties. $\quad$ (2005). Paraná. Retrieved March 2010, http://www.cnpf.embrapa.br/publica/comuntec/edicoes/com_tec136.pdf

Jara, C. J. (1998). Sustainability of Local Development-Challenges in Building a Process. Brasilia: the Inter-American Institute for Cooperation on Agriculture (IICA).

Kyoto, Protocol. (1997). Convention-United Nations Framework on Climate Change. Retrieved October 17, 2009, from http://www.mct.gov.br/index.php/content/view/28739.html

LIVESTOCK. (2012). Cotação da Arroba de Boi Para Abate. Retrieved November 29, 2012, from http://www.pecuaria.com.br/cotacoes.php

M Ethodology of Scientific Knowledge. (2000). São Paulo: Atlas. 
Manual of Forestry. (2008). Minas Gerais. Retrieved July 12, 2010, from http://www.arcelormittalbioenergia.com.br/arquivos/38_manual.pdf

Marafon, G. J., \& Brook, M. A. (2004). Family Farming and Rural Tourism in the State of Rio de Janeiro. Rio de Janeiro. Retrieved October 6, 2009, from http://www.sober.org.br/palestra/5/244.pdf

Ministry of the Environment-Mma. (2002). Eligibility Criteria and Indicators for Sustainability Assessment Project that Contribual for Climate Change Mitigation and the Promotion of Sustainable Development (p. 42). Brasília.

Neto, A. A. (2006). Financial Mathematics and Its Applications. Sao Paulo: Atlas.

New Directions for Fluminense Economy. (2008). Opportunities and Challenges of Growth of the Interior. Rio de Janeiro: Editora e-papers.

Nozoe, N. (2009). Sesmarias Possession and Land in Colonial Brazil. Department of Economics, Faculty of Economics, Management and Accounting. University of São Paulo: FEA-USP, São Paulo. Retrieved October 5, 2009, from http://www.anpec.org.br/revista/vol7/vol7n3p587_605.pdf

Plant Carbon Project. (2204). Minas Gerais. Retrieved July 17, 2010, from http://www.plantar.com.br/portal/page/portal/plantar/projeto_carbono/introducao

Puentes, Renzo Sebastián Eduardo Solari. (2010). Expansion Of Planted Forests in Brazil With Energy Purposes And Its Influence In Emissions Of Greenhouse Effect Gases-GHG: Analysis Of Two Future Scenarios. (Master thesis). Retrieved from Combra Luiz Alberto Institute of Postgraduate Studies and Research (COPPE), Federal University of Rio de Janeiro, Rio de Janeiro.

Renner, Rosana Maria. (2004). And Carbon Sequestration Feasibility of New Reforestation in Brazil. Dissertation (Master thesis), Department of Agricultural Sciences, Universidade Federal do Paraná, Curitiba.

Rodigheri, H. R. (2010). Forestry as an Alternative to Increased Employment and Income in Rural Land. Retrieved May 9, 2010, from http://www.cnpf.embrapa.br/publica/circtec/edicoes/circ-tec42.pdf

Schier. (2005). Controller CUC-As a Management Tool. São Paulo: Editora Juruá.

Segala, C. Z. S., \& Silva, I. T. (2010). Counting the cost of milk production on a farm in the municipality of Irani-SC. $\quad$ Retrieved January $29, \quad 2010, \quad$ from http://www.custoseagronegocioonline.com.br/numerolv3/Custos\% 20the\% 20leite.pdf

Sepúlveda, S., Wilkinson, J., Tiburcio, B., \& Herrera, S. (2008). Agroeneria and Development of Isolated Rural Communities. Brasilia: IICA.

Shell, J. Y., Alegre, J. C., \& Pocomucha, V. (2007). Reservations Determinación of them in her Biomass Carbon Air Systems Theobroma Cacao L. Agroflorestales of in el Department of San Martín, Peru. Costa Rica. Retrieved November 28, 2009, from http://revistas.concytec.gob.pe/pdf/ecol/v3n1-2/a25v3n1-2.pdf

Sources, A. A., Da Silva, M. L., Valverde, S. R., \& Souza, A. L. (2003). Analysis of Forest Activities in the municipality of Viçosa-MG Minas Gerais: Society of Forest Research - Tree Magazine, 27(4), $517-525$.

Spode, R. D. (2007). Profitability Economic Culture of Eucalyptus Benefited with Carbon Credits. 78F. Working End of Course (Specialization in Capital Markets) Graduate Program in Management, Federal University of Rio Grande do Sul, Porto Alegre.

Supply Chain Wood. (2007). volume 6, Brasília.

Tasso, D. C., \& Birth, E. Q. (2005). Kyoto Protocol-Analysis of Financial Aspects of Carbon Market. In: Scientific Symposium Fucape Production, 3, 2005. Victory. Annals electronic ... Win: Fucape, 2005. Retrieved October 22, 2009, from http:/www.fucape.br/simposio/3/artigos/carla20tasso $\% \% \% 20 \mathrm{e} \%$ 20edson 20queiroz.pdf

Thyssenkrupp Steel. (2010). Rio de Janeiro. Retrieved July 2, 2010, from http://www.thyssenkrupp-steel-europe.com/csa/pt/index.jsp

Toledo, P. (2001). The Clean Development Mechanism and Restoration Forestry. Economic Information, SP, $31(3)$.

UFPR; ECOPLAN. (2003). Feasibility study for establishment of forests fixing carbon: a case study in the southern state of Paraná (p. 93). Curitiba. 
UNFCCC. (2010). Frequently Asked Questions. Retrieved July 2, 2010, from http://unfccc.int/ghg_data/online_help/frequently_asked_questions/items/3826.php

Vale. (2010). What We Do Steel. Rio de Janeiro. Retrieved July 2, 2010, from http://www.vale.com/pt-br/o-que-fazemos/siderurgia/paginas/default.aspx

Vieira, A. M. (2010). Energy Forests and Charcoal Production in Brazil.

Walnut, M. P. (2004). Fastening Technology and Human Field. São Paulo. Retrieved September 20, 2009, from Article in Portuguese.

\section{Copyrights}

Copyright for this article is retained by the author(s), with first publication rights granted to the journal.

This is an open-access article distributed under the terms and conditions of the Creative Commons Attribution license (http://creativecommons.org/licenses/by/3.0/). 